\title{
ANALISIS PERILAKU INSTABILITAS PEREKONOMIAN INDONESIA: PENDEKATAN KETERKAITAN EKONOMI MAKRO, PERDAGANGAN INTERNASIONAL DAN SEKTOR PERTANIAN
}

\author{
Andi Irawan \\ Perry Warjiyo ${ }^{1}$
}

\begin{abstract}
In general the aim of this study is to investigate short-run relationships among macroeconomy, international trade and agriculture in Indonesia. Under such circumstances, the specific goals of this research is to analyze which economic blocks that have most affected by instability, as well as producing instability in the economy.

We apply the Vector Error Correction Model on monthly series data from 1993:01 to 2002:12. The main result of this study shows as follow: 1) that the asset financial and the commodity demand blocks the most producing instability in the economy. On the other hand, the export block producing the least instability to the economy. The finding suggest that government should concentrate attention on asset financial and the commodity demand blocks in stabilizing the economy, as they are major sources of instability of the economy.

2) To stabilize the commodity demand, it is also necessary to stabilize the financial market, as the assets demand block is the most contributor of the instability in the commodity demand block. In other words, money demand is the main source of instability. Because money supply is determined by government, the disequlibrium error measure the excess supply of money in the market. This suggest that monetary policy that reduces the disequlibrium error can help stabilize the economy.
\end{abstract}

JEL Classification: C22, F17, Q11, Q18

Keyword: Instabilitas, Disequilibrium Error, perdagangan internasional, pertanian, VECM, fiscal policy

\footnotetext{
${ }^{1}$ Andi Irawan adalah staf pengajar pada Universitas Bengkulu dan Universitas Paramadina Jakarta. Perry Warjiyo adalah peneliti dan direktur Direktorat Riset dan Kebijakan Moneter, Bank Indonesia.
} 


\section{PENDAHULUAN}

\subsection{LATAR BELAKANG}

Shock (guncangan) dalam suatu perekonomian adalah suatu keniscayaan. Terminologi ini merujuk pada apa-apa yang menjadi penyebab ekspansi dan kontraksi atau sering juga disebut sebagai fluktuasi ekonomi. Umumnya kajian-kajian ekonomi makro bertujuan menguji kepentingan relatif guncangan-guncangan dan dinamika variabel ekonomi makro akibat guncangan ini (Supriana, 2004). Sehubungan dengan fenomena shock ini adalah sangat menarik berbicara tentang sumber dan dampak suatu shock ekonomi (instabilitas) dalam konteks Indonesia khususnya selama era reformasi ini ${ }^{2}$, dimana ada sejumlah fenomena-fenomena penting yang menunjukkan adanya instabilitas ekonomi yang layak untuk dieksplorasi lebih dalam implikasinya dan dampaknya bagi perekonomian secara keseluruhan. Indikasi fenomena-fenomena tersebut dan faktorfaktor penyebabnya terangkum dalam Lampiran 1.

Sedangkan sektor/blok ekonomi yang menarik untuk dikaji baik sebagai sumber instabilitas (penghasil shock/guncangan) ataupun sebagai penerima instabilitas berdasarkan fenomena ekonomi selama era krisis ekonomi sampai saat ini adalah sebagai berikut:

1. Blok permintaan komoditas, blok ini penting dikaji mengingat selama periode menjelang krisis (triwulan kedua 1997) sampai pasca krisis diketahui kontribusi yang terbesar yang menentukan pembentukan Produk Domestik Bruto Indonesia adalah konsumsi rumahtangga yakni berkisar antara 67 persen sampai 81 persen per triwulan. Dengan demikian sangat penting untuk memahami atau menentukan shock yang menentukan blok permintaan komoditas ini, dan bagaimana dampak instabilitas dari blok ini terhadap blok ekonomi di luar dirinya.

2. Blok Finansial, sebagaimana yang telah diuraikan dalam Tabel 1 sektor finansial termasuk sektor yang paling krusial baik sebagai sumber instabilitas bagi sektor ekonomi lain maupun sebagai penerima instabilitas dari luar. Pengalaman dari krisis ekonomi menunjukkan sektor ini termasuk yang pertama kali mengalami guncangan akibat dari instabilitas ekonomi kawasan Asia Tenggara.

3. Blok produksi pertanian dan non pertanian, kedua blok ini penting untuk diketahui perilakunya sehubungan dengan adanya fenomena yang berbeda antara produksi

\footnotetext{
${ }^{2}$ Era reformasi merujuk pada pemerintahan yang terbentuk pasca lengsernya presiden Soeharto
} 
pertanian dan non pertanian pada saat krisis ekonomi terjadi. Saat krisis pada kondisi parah yang ditunjukkan dengan pertumbuhan PDB negatif yakni sepanjang triwulan pertama 1998 sampai triwulan pertama 1999, tampak bahwa sektor pertanian tetap bisa tumbuh dimana pada triwulan 1 dan triwulan 3 tahun 1998 pertumbuhan sektor pertanian masing-masing adalah 11.2 persen, sedangkan pada triwulan 1 tahun 1999 tumbuh 17.5 persen. Adapun umumnya sektor non pertanian pada periode krisis ekonomi yang parah tersebut pertumbuhannya adalah negatif (lihat Tabel 2). Dengan demikian bagaimana dampak instabilitas dan shock ekonomi terhadap blok produksi pertanian dan non pertanian serta bagaimana dampak instabilitas dari blok ini terhadap blok ekonomi di luar dirinya menarik untuk dikaji. Disamping perilaku output, blok produksi ini juga akan mencakup perilaku investasi dan permintaan tenaga kerja (employment) dari sektor pertanian dan non pertanian.

Tabel 2. Pertumbuhan Sektor-sektor Ekonomi Selama Periode Krisis Ekonomi yang Parah

\begin{tabular}{|c|c|c|c|c|c|}
\hline \multirow[t]{2}{*}{ Sektor Ekonomi } & \multicolumn{4}{|c|}{$1998(\%)$} & \multirow{2}{*}{$\begin{aligned} 1999(\%) \\
\text { Triwulan I }\end{aligned}$} \\
\hline & Triwulan I & Triwulan II & Triwulan III & Triwulan IV & \\
\hline Pertanian & -11.20 & 2.81 & -2.42 & 7.99 & 17.50 \\
\hline $\begin{array}{l}\text { Pertambangan dan } \\
\text { Penggalian }\end{array}$ & 0.22 & -5.12 & -5.14 & -0.93 & -2.28 \\
\hline Industri Pengolahan & 0,80 & -15.39 & -13.14 & -16.97 & -6.13 \\
\hline $\begin{array}{l}\text { Listrik, Gas dan Air } \\
\text { Bersih }\end{array}$ & 7.18 & 1.74 & 0.98 & 2.62 & 4.27 \\
\hline Bangunan & -22.44 & -39.23 & -44.53 & -39.43 & -23.85 \\
\hline $\begin{array}{l}\text { Perdagangan, Hotel, } \\
\text { dan Restoran }\end{array}$ & -0.28 & -17.36 & -24.60 & -28.58 & -14.62 \\
\hline $\begin{array}{l}\text { Pengangkutan dan } \\
\text { Komunikasi }\end{array}$ & -0.66 & -14.32 & -21.84 & -23.29 & -17.71 \\
\hline $\begin{array}{l}\text { Keuangan, } \\
\text { Persewaan, dan Jasa }\end{array}$ & -6.82 & -24.82 & -25.74 & -44.17 & -21.87 \\
\hline Jasa-Jasa & -4.27 & -2.45 & -4.35 & -4.29 & 2.05 \\
\hline PDB & -4.48 & -13.34 & -16.00 & -18.25 & -6.131 \\
\hline
\end{tabular}


4. Blok Permintaan Ekspor, Blok ini penting untuk dikaji perilakunya ketika adanya instabilitas ekonomi mengingat pada periode krisis ekonomi ada fenomena yang menarik dimana turunnya nilai tukar rupiah terhadap dolar tidak menyebabkan peningkatan pertumbuhan ekspor Indonesia. Fakta empiris menunjukkan ketika terjadi depresiasi rupiah yang lebih besar pada tahun 1998 dan tahun 1999 (nilai tukar pada periode tersebut berkisar antara Rp 7100 per dolar Amerika Serikat sampai Rp 11590 per dolar Amerika Serikat), nilai ekspor lebih rendah dibanding tahun 1997. Nilai ekspor pada tahun 1998 dan 1999 masing-masing sebesar 95.8 milyar rupiah dan 91.8 milyar rupiah, bandingkan dengan nilai ekspor tahun 1997 yang sebesar 121.2 milyar rupiah padahal nilai tukar pada tahun 1997 berkisar antara Rp 2400 per dolar Amerika Serikat sampai Rp 4000 per dolar Amerika Serikat.

Dengan semakin terbukanya ekonomi Indonesia dengan ekonomi internasional akan berimplikasi eksisnya pengaruh variabel-variabel makro ekonomi dan ekonomi internasional terhadap kinerja blok-blok ekonomi di atas, begitu juga akan ada saling interaksi antar veriabel-variabel ekonomi antar blok. Hal ini juga berimplikasi bahwa rancangan kebijakan ekonomi yang bertujuan menstabilisasi sektor pertanian dan non pertanian serta sektor ekonomi lainnya tidak bisa lepas dari bagaimana kebijakan tersebut dilakukan secara integratif baik yang menyangkut dari sisi ekonomi pertanian, kebijakan ekonomi makro dan kebijakan perdagangan internasional.

\subsection{TUJUAN PENELITIAN}

Berdasarkan uraian di atas penelitian ini bertujuan sebagai berikut; Sektor atau blok ekonomi mana yang menjadi sumber instabilitas penting bagi perekonomian, dan blok atau sektor ekonomi mana yang paling banyak menerima guncangan dari blok ekonomi di luar dirinya. 


\section{METODE PENELITIAN}

\subsection{SPESIFIKASI MODEL VECM ${ }^{3}$}

Model penelitian mengandung 35 Variabel, dengan demikian vektor Z merupakan vektor 35 x 1 sebagai berikut:

$\mathrm{Z}_{\mathrm{t}}=(\mathrm{LPA}, \mathrm{LPN}, \mathrm{LPBINA}, \mathrm{LPBINN} 1, \mathrm{LX}, \mathrm{LPM}, \mathrm{LPB}, \mathrm{LPBIN} \mathrm{B}, \mathrm{LW}, \mathrm{LWA} / \mathrm{LPA}$, LPMA/LPA, r, LWN/LPN, LPMN/LPN, LP_A, LP_N, LXBIN, LREER, LC A, LC $_{\mathrm{N}}$, LC_BINA, LCBIN_N1, LM2, LB, LBBIN, LYA, LLA, LKA, LYN, LLN, LKN, LC_A, LC_N)

Jika VARnya memiliki ordo $p$ maka $Z_{t}$ menjadi:

$$
Z_{t}=\sum_{i=1}^{p} \prod_{i} Z_{t-i}+\varepsilon_{t}
$$

Persamaan 1 di atas dapat ditulis dalam bentuk first difference sebagai berikut:

$$
\Delta \mathrm{Z}_{\mathrm{t}}=\prod_{\mathrm{i}} \mathrm{Z}_{\mathrm{t}-\mathrm{i}}+\sum_{\mathrm{i}=1}^{\mathrm{p}-1} \Gamma_{\mathrm{i}} \Delta \mathrm{Z}_{\mathrm{t}-\mathrm{i}}+\varepsilon_{\mathrm{t}}
$$

dimana: $\quad \prod \quad=\alpha \beta$ adalah matrik $34 \times 34$ parameter

$\Delta \mathrm{Z}_{\mathrm{t}} \quad=$ vektor first difference

$\Gamma_{\mathrm{i}} \quad=34 \times 34$ matrik koefisien

$\varepsilon_{\mathrm{t}} \quad=34 \times 1$ vektor proses white noise

$\beta=34 \times 15$ cointegrating vector

$\alpha \quad=34 \times 15$ matrik koefisien

Matriks $\beta$ dapat diestimasi dengan menggunakan regresi kointegrasinya sehingga dapat dihasilkan error correction term $\mathrm{E}_{\mathrm{t}-1}=\beta \mathrm{Z}_{\mathrm{t}-1}$. Dengan demikian $\prod_{\mathrm{i}} \mathrm{Z}_{\mathrm{t}-\mathrm{i}}$ dapat diestimasi sebagai $\alpha \mathrm{E}_{\mathrm{t}-1}$. Komponen $\mathrm{E}_{\mathrm{t}-1}$ merupakan $15 \times 1$ vektor disequilibrium error jangka panjang. Adapun analisis Vector Error Correction Model adalah sebagai berikut:

\footnotetext{
${ }^{3}$ Penjelasan Struktur dasar model dan proses optimisasi oleh agen (perusahaan dan konsumen) serta teknik prosedur ekonometrika dengan pendekatan VECM ini dapat dilihat secara lengka dalam Irawan (2005)
} 


\subsubsection{BLOK PERMintaAn Komoditas}

Vector Error Correction Model digunakan untuk menganalisis sumber ketidakstabilan dalam blok permintaan komoditas dengan rumus sebagai berikut:

$$
\Delta \mathrm{Z}_{1, \mathrm{t}}=\alpha_{1} \mathrm{E}_{\mathrm{t}-1}+\sum_{\mathrm{i}=1}^{\mathrm{p}-1} \Gamma_{1} \Delta \mathrm{Z}_{1, \mathrm{t}-\mathrm{i}}+\varepsilon_{1 \mathrm{t}}
$$

dimana: $\Delta \mathrm{Z}_{1}$ adalah $10 \mathrm{x} 1$ vektor variabel yang ada dalam blok permintaan komoditas

$\alpha_{1}$ adalah $10 \times 15$ matrik koefisien

$\mathrm{E}_{\mathrm{t}-1}$ adalah $15 \mathrm{x} 1$ vektor error correction (long run disequilibrium error)

\subsubsection{BLOK PERMintaAn ASET}

Vector error correction model yang digunakan untuk mendeteksi sumber ketidakstabilan di dalam blok permintaan aset adalah sebagai berikut:

$$
\Delta Z_{2, t}=\alpha_{2} E_{t-1}+\sum_{i=1}^{p-1} \Gamma_{2} \Delta Z_{2, t-i}+\varepsilon_{2 t}
$$

dimana: $\quad Z_{2} \quad$ adalah vektor 7 x 1 dari variabel-variabel LPM, LPB LPBIN_B, LM2, LB, LBBIN dan LW

$\mathrm{E}_{\mathrm{t}-1}$ adalah error correction term pada periode sebelumnya pada setiap persamaan pada masing-masing blok

$\alpha_{2} \quad$ adalah $7 \times 15$ matrik koefisien 


\subsubsection{BLOK PRODUKSI PERTANIAN}

Tujuan utama dari analisis error correction model pada blok ini adalah untuk mengidentifikasi sumber dari instabilitas penawaran (produksi) dan pemintaan input dalam blok produksi pertanian. Adapun persamaan vector error correction modelnya adalah sebagai berikut:

$$
\Delta Z_{3, t}=\alpha E_{t-1}+\sum_{i=1}^{p-1} \Gamma_{i} \Delta Z_{3, t-i}+\varepsilon_{3 t}
$$

dimana: $\quad Z_{3}$ adalah $7 \times 1$ vektor untuk variabel-variabel $\left(1 \mathrm{wa} / 1 \mathrm{p}_{\mathrm{A}}, 1 \mathrm{P}_{\mathrm{mA}} / 1 \mathrm{P}_{\mathrm{A}}, \mathrm{r}, 1 \mathrm{P}_{\mathrm{A}}\right.$, $1 \mathrm{Y}_{\mathrm{A}}, 1 \mathrm{~L}_{\mathrm{A}}$ dan $\left.1 \mathrm{~K}_{\mathrm{A}}\right)$

$\mathrm{E}_{\mathrm{t}-1}$ adalah error correction term pada setiap persamaan pada masingmasing blok pada periode sebelumnya

$\alpha_{3}$ adalah 7 x 15 matrik koefisien

\subsubsection{BLOK PRODUKSI NON PERTANIAN}

Tujuan utama dari analisis error correction model pada blok ini adalah untuk mengidentifikasi sumber dari instabilitas penawaran (produksi) dan pemintaan input dalam blok produksi non pertanian. Adapun persamaan vector error correction modelnya adalah sebagai berikut:

$$
\Delta \mathrm{Z}_{4, \mathrm{t}}=\alpha \mathrm{E}_{\mathrm{t}-1}+\sum_{\mathrm{i}=1}^{\mathrm{p}-1} \Gamma_{\mathrm{i}} \Delta \mathrm{Z}_{4, \mathrm{t}-\mathrm{i}}+\varepsilon_{4 \mathrm{t}}
$$

dimana: $\quad Z_{4}$ adalah $7 \times 1$ vektor untuk variabel-variabel (LWNPN, LPMNPN,, $\mathrm{LP}_{\mathrm{N}}, \mathrm{LYN}, \mathrm{LL}_{\mathrm{N}}$ dan $\left.\mathrm{LK}_{\mathrm{N}}\right)$

$\mathrm{E}_{\mathrm{t}-1}$ adalah error correction term pada setiap persamaan pada masingmasing blok pada periode sebelumnya $\alpha_{3}$ adalah $7 \times 15$ matrik koefisien 


\subsubsection{BLOK PERMINTAAN EKSPOR}

Tujuan utama dari analisis error correction model pada blok ini adalah untuk mengidentifikasi sumber dari instabilitas dalam blok permintaan ekspor. Adapun persamaan vector error correction modelnya adalah sebagai berikut:

$$
\Delta \mathrm{Z}_{5, \mathrm{t}}=\alpha \mathrm{E}_{\mathrm{t}-1}+\sum_{\mathrm{i}=1}^{\mathrm{p}-1} \Gamma_{\mathrm{i}} \Delta \mathrm{Z}_{5, \mathrm{t}-\mathrm{i}}+\varepsilon_{5 \mathrm{t}}
$$

dimana: $\quad Z_{4}$ adalah $7 \times 1$ vektor untuk variabel-variabel (LC_A, LC_N, LREER, LP_A, LP_N, dan LX_BIN)

$\mathrm{E}_{\mathrm{t}-1}$ adalah error correction term pada setiap persamaan pada masingmasing blok pada periode sebelumnya

$\alpha_{3}$ adalah $6 \times 15$ matrik koefisien

\subsection{DATA}

Data yang digunakan adalah data runtut waktu bulanan 1993:01 sampai 2002:12 diperoleh dari publikasi statistik lembaga-lembaga berikut: Bank Indonesia (BI), Badan Pusat Satistik (BPS), CEIC data Company limited dan dari International Financial Statistics IMF. Sampel observasi data dipilih dari tahun 1993 - 2002 karena mempertimbangkan pada jangka waktu tersebut ekonomi Indonesia telah terintegrasi secara siknifikan dengan perekonomian internasional yang ditandai oleh dengan lahirnya kebijakan-kebijakan yang bersifat outward looking seperti deregulasi perekonomian dan liberalisasi sektor pertanian. Sedangkan data bulanan yang dipilih karena pertimbangan teknis statistik untuk mengatasi masalah degree of freedom mengingat jika digunakan series tahunan atau triwulanan akan mengalami masalah degree of freedom. Adapun rincian variabel, data yang digunakan, teknik perhitungannya serta dan data dapat dilihat pada Tabel 3. 


\section{HASIL DAN ANALISIS}

\subsection{BLOK PERMINTAAN KOMODITAS}

Keseluruhan hasil estimasi diberikan pada Lampiran 3. Tabel 4 merangkum koefisien-koefisien disequilibrium error $^{4}$ dari masing-masing persamaan error correction model untuk blok permintaan komoditas. Nama variabel, penjelasan dan sumber data selengkapnya diberikan pada Lampiran 2. Sejumlah temuan empiris penting yang dapat dilihat dari tabel 4 adalah sebagai berikut: Pertama, diantara empat blok diluar blok permintaan komoditas, blok permintaan aset finansial tampaknya memberikan eksternalitas yang terbesar terhadap blok permintaan komoditas dibandingkan blok-blok lainnya. Hal ini ditunjukkan jumlah koefisien disequilibrium error yang siknifikan pengaruhnya terhadap persamaan-persamaan blok permintaan komoditas dengan jumlah terbanyak berasal dari blok aset finansial. Hal ini mengindikasikan permintaan komoditas memiliki volatilitas yang lebih tinggi terhadap gangguan (disturbances) dari blok/ pasar aset finansial dibanding dari disturbances blok lainnya, atau dengan kata lain blok aset finansial menjadi sumber instabilitas tertinggi bagi blok permintaan komoditas. Hal ini tidak mengherankan karena aset finansial dapat bersifat subtitusi terhadap komoditas dalam arti membeli aset finansial yang lebih banyak saat ini akan mengurangi konsumsi atas komoditas, dan sebaliknya. Sumber instabilitas penting lainnya bagi blok permintaan komoditas adalah berasal dari blok produksi non pertanian, sedangkan yang paling kecil dampak gangguannya adalah berasal dari blok produksi pertanian dan blok permintaan ekspor.

Kedua, Kalau dilihat dari disequlibrium error yang berasal dari dalam blok permintaan komoditas, maka disequlibrium error dari permintaan komoditas pertanian domestik memberikan dampak/spillover (guncangan) terbesar terhadap blok permintaan komoditas diikuti selanjutnya oleh permintaan komoditas non pertanian domestik. Hal ini juga tampaknya senada dengan hasil studi Zaini (2003) yang mengatakan bahwa sektor pertanian mempunyai multiplier effect terhadap pendapatan rumahtangga yang lebih besar dibandingkan dengan sektor non pertanian dimana untuk sektor pertanian multiplier

\footnotetext{
${ }^{4}$ Terminologi disequilibrium error, disturbance, spillover dan eksternalitas pada bab ini dan seterusnya adalah beberapa istilah yang merujuk pada konsep yang sama (lihat Sugema (1992) dan Beck and Winker (2004) yakni deviasi antara keseimbangan jangka panjang dan data faktualnya, dimana deviasi ini merupakan sumber shock terhadap variabel endogenus yang dipengaruhinya.
} 
effectnya berkisar antara 1.62 - 1.91 yang berarti pengembangan sektor pertanian sebesar 1 satuan rupiah akan berdampak pada kenaikan pendapatan rumahtangga sebesar $1.62-1.91$ satuan rupiah pada sektor pertanian terkait, bandingkan dengan multiplier effect terhadap pendapatan rumahtangga dari sektor non pertanian yang hanya berkisar antara $0.55-1.68$. Sedangkan disequilibrium error permintaan komoditas non pertanian impor dan permintaan komoditas pertanian impor memberikan dampak/spillover yang terkecil.

Ketiga, diantara empat persamaan permintaan komoditas, permintaan komoditas pertanian impor menerima dampak/spillover yang terbesar dari luar sistem/blok permintaan komoditas, spillover yang dimaksud berasal dari penawaran (output) pertanian dan non pertanian, permintaan tenaga kerja non pertanian, permintaan ekspor pertanian dan non pertanian, dan permintan bond luar negeri. Hal ini mengindikasikan beberapa hal yakni: 1) bahwa permintaan komoditas pertanian impor sangat responsive terhadap berbagai guncangan dari luar, 2) Mengatasi dilema masuknya komoditas impor membutuhkan kebijakan yang kompleks dan rumit karena banyak faktor yang mampu menyebabkan shock terhadap permintaan impor komoditas pertanian, dari sumber spillover menunjukkan bahwa fenomena impor komoditas pertanian bukan hanya terkait dengan masalah kelebihan atau kekurangan suplai domestik dari komoditas pertanian domestik saja, tetapi juga karena faktor-faktor lain. Oleh karena itu tidak cukup mengatasi impor komoditas yang marak di era reformasi hanya dengan mengatasi melalui kebijakan membatasi masuknya komoditas impor melalui halangan tarif atau non tarif.

Sedangkan untuk permintaan komoditas non pertanian impor, relatif penyebab guncangan tidak banyak yakni hanya berasal dari disequilibrium error penawaran komoditas non pertanian domestik, sehingga dapat diprediksi kemungkinan impor komoditas non pertanian domestik lebih banyak disebabkan oleh masalah-masalah guncangan penawaran komoditas non pertanian domestik. Faktor lain yang menjadi sumber guncangan adalah permintaan bond luar negeri, penulis menduga hal ini karena terjadinya disequilibrium permintaan bond luar negeri dalam bentuk lonjakan permintaan di atas keseimbangan jangka panjangnya akan berimbas pada nilai tukar yang selanjutnya perubahan nilai tukar ini akan menjadi sumber shock bagi permintaan impor komoditas non pertanian domestik. 
Keempat, untuk disequilibrium error yang berkaitan dengan pertanian tampak bahwa yang berpengaruh siknifikan secara statistik terhadap sejumlah persamaan di luar pertanian adalah disequilibrium error permintaan komoditas pertanian domestik, disequilibrium error permintaan tenaga kerja pertanian, disequilibrium error penawaran output pertanian dan disequilibrium error permintaan ekspor pertanian. Fenomena ini mengindikasikan adanya feed back (umpan balik) sektor pertanian terhadap sektor non pertanian. Hal ini merupakan temuan penting karena menunjukkan stabilisasi sektor pertanian akan mempengaruhi sejumlah komponen ekonomi di luar sektor pertanian.

\subsection{BLOK PERMINTAAN ASET}

Tabel 5 merangkum variabel-variabel disequlibrium error yang dapat menjadi sumber instabilitas dari blok permintaan aset finansial. Ada sejumlah temuan empiris penting yang dapat dilihat pada tabel 5 tersebut, pertama, disequilibrium error M2 berpengaruh siknifikan terhadap permintaan aset finansial lainnya khususnya bond luar negeri, begitu juga disequilibrium error dari permintaan bond domestik dan luar negeri juga berpengaruh siknifikan terhadap permintaan M2. hal ini menunjukkan bahwa kuantitas uang tidak semata-mata ditentukan oleh pemerintah tetapi juga dipengaruhi oleh permintaan pasar. Kedua, diatara harga-harga aset finansial, tampak bahwa harga implisit bond domestik paling banyak mendapatkan pengaruh (spillover) baik dari dalam maupun dari luar blok permintaan aset. Tabel 5 juga menunjukkan bahwa tidak ada spillover baik dari dalam maupun dari luar blok permintaan aset terhadap harga implisit bond luar negeri.

\subsection{BLOK PRODUKSI PERTANIAN}

Tabel 6 menyajikan ringkasan koefisien dari disequilibrium error dari setiap persamaan dalam masing-masing blok ekonomi terhadap blok produksi pertanian. Beberapa temuan empiris yang dapat dilihat dari tabel 6 adalah, pertama, koefisienkoefisien disequilibrium error sumber guncangan bagi output pertanian telah sesuai dengan yang diharapkan dimana: 1) Tanda negatif pada koefisien disequilibrium error output menunjukkan bahwa jika terjadi lonjakan penawaran di atas keseimbangan jangka panjangnya akan menjadi sumber guncangan yang menurunkan produksi pertanian. 2) Tanda positif pada koefisien disequilibrium error permintaan modal menunjukkan jika terjadi kelebihan permintaan modal di atas keseimbangan jangka panjangnya akan menjadi sumber guncangan yang meningkatkan output (produksi) pertanian. 3) Tanda negatif pada 
koefisien disequilibrium error permintaan tenaga kerja menunjukkan bahwa jika terjadi lonjakan permintaan tenaga kerja di atas keseimbangan jangka panjangnya akan menjadi sumber guncangan yang menaikkan output (produksi) pertanian. Tiga hal ini menunjukkan bahwa pertumbuhan output pertanian sangat rentan terhadap adanya shock produksi, permintaan modal dan permintaan tenaga kerja pertanian.

Kedua, koefisien-koefisien disequilibrium error sumber guncangan bagi upah riil sektor pertanian juga telah sesuai dengan yang diharapkan dimana: 1) Tanda positif pada koefisien disequilibrium error output menunjukkan jika terjadi shock penawaran di atas keseimbangan jangka panjangnya misalnya pada saat panen raya maka akan menjadi sumber guncangan yang meningkatkan upah rill tenaga kerja pertanian karena pada saat itu terjadi peningkatan permintaan tenaga kerja sehingga menjadi sumber shock peningkatan upah tenaga kerja pertanian. 2) Tanda negatif pada koefisien disequilibrium error permintaan tenaga kerja menunjukkan jika terjadi lonjakan permintaan tenaga kerja di atas keseimbangan jangka panjangnya akan menjadi sumber guncangan yang menurunkan tingkat upah riil tenaga kerja pertanian. 3) Tanda negatif pada koefisien disequilibrium error permintaan modal menunjukkan jika terjadi lonjakan permintaan modal di atas keseimbangan jangka panjangnya akan menjadi sumber guncangan yang menurunkan upah riil tenaga kerja pertanian. Hal ini mengindikasikan hubungan modal dan tenaga kerja yang saling subtitusi dimana kelebihan permintaan modal cenderung menurunkan permintaan tenaga kerja. Turunnya permintaan tenaga kerja mengakibatkan turun pula tingkat upah tenaga kerja sektor pertanian.

Ketiga, koefisien-koefisien disequilibrium error sumber guncangan bagi harga output pertanian telah sesuai dengan yang diharapkan dimana: 1) Tanda negatif pada koefisien disequilibrium error output menunjukkan jika terjadi lonjakan penawaran di atas keseimbangan jangka panjangnya akan menjadi sumber guncangan yang menurunkan harga output pertanian. 2) Tanda positif pada koefisien disequilibrium error permintaan modal menunjukkan jika terjadi lonjakan permintaan modal di atas keseimbangan jangka panjangnya akan menjadi sumber guncangan yang meningkatkan harga output pertanian. Hal ini karena kelebihan permintaan modal berimplikasi pada naiknya harga barang modal yang selanjutnya akan meningkatkan biaya produksi. Peningkatan biaya produksi inilah yang selanjutnya menjadi penyebab naiknya harga output 3) Tanda positif pada koefisien disequilibrium error permintaan tenaga kerja menunjukkan jika terjadi lonjakan 
permintaan tenaga kerja di atas keseimbangan jangka panjangnya akan menjadi sumber guncangan yang menaikkan harga output pertanian. Hal ini karena lonjakan permintaan tenaga kerja tersebut menyebabkan terjadinya naiknya harga tenaga kerja yang berimplikasi pada naiknya biaya input tenaga kerja. Kenaikan input tenaga kerja ini menyebabkan naiknya harga output pertanian.

Keempat, Tanda koefisien disequilibrium error permintaan modal non pertanian yang mempengaruhi output pertanian adalah negatif dan siknifikan yang berarti jika terjadi lonjakan permintaan modal non pertanian di atas keseimbangan jangka panjangnya akan menjadi sumber shock yang menurunkan produksi (output) pertanian. Hal ini mengindikasikan lonjakan permintaan modal non pertanian tersebut selanjutnya menjadi sumber shock yang bisa menurunkan produksi.

Kelima, tanda koefisien-koefisien disequilibrium error permintaan aset finansial (permintaan M2, permintaan bond dalam negeri dan permintaan bond luar negeri) yang mempengaruhi produksi pertanian semuanya bertanda negatif dan siknifikan secara statistik. Hal ini menunjukkan terjadinya lonjakan permintaan ketiga aset finansial tersebut di atas keseimbangan jangka panjangnya akan memacu kenaikan harga-harga umum termasuk harga komoditas pertanian, dimana kenaikan harga komoditas pertanian ini akan memacu produsen pertanian untuk meningkatkan produksi mereka.

Keenam, jumlah disequlibrium error yang siknifikan mempengaruhi harga (input dan output pertanian) ternyata lebih besar dibandingkan dengan jumlah disequilibrium error yang mempengaruhi kuantitas (produksi output dan permintaan input). Hal ini mengindikasikan instabilitas dalam blok produksi pertanian ini lebih terkait oleh guncangan/ perubahan pada harga-harga (input ataupun output) dibanding karena guncangan/ perubahan kuantitas (output ataupun input).

\subsection{BLOK PRODUKSI NON PERTANIAN}

Tabel 7 menyajikan ringkasan koefisien dari disequilibrium error dari setiap persamaan dalam masing-masing blok ekonomi terhadap blok produksi non pertanian. Beberapa temuan empiris yang bermakna secara ekonomi dapat dilihat pada tabel 7 .

Pertama, koefisien-koefisien disequilibrium error yang mempengaruhi output non pertanian menunjukkan hal-hal sebagai berikut: 1) Tanda negatif pada koefisien disequilibrium error output menunjukkan jika terjadi lonjakan penawaran di atas keseimbangan jangka panjangnya akan mennjadi sumber guncangan yang menurunkan 
produksi non pertanian. 2) Tanda positif pada koefisien disequilibrium error permintaan tenaga kerja menunjukkan jika terjadi lonjakan permintaan tenaga kerja di atas keseimbangan jangka panjangnya akan menjadi sumber guncangan yang menaikkan produksi pertanian. Dua temuan ini menunjukkan bahwa pertumbuhan output non pertanian sangat rentan terhadap adanya shock yang berasal dari dalam blok produksi non pertanian itu sendiri khususnya shock produksi dan shock permintaan tenaga kerja non pertanian. Di era reformasi ini kemungkinan terjadinya shock permintaan tenaga kerja akan sangat tinggi mengingat semakin bebas organisasi buruh dibentuk dan semakin tingginya posisi tawar mereka. Adapun shock dari luar blok produksi non pertanian ternyata tidak ada yang siknifikan mempengaruhi output non pertanian secara langsung.

Kedua, disequilibrium error output pertanian ternyata siknifikan mempengaruhi permintaan modal non pertanian, tanda koefisien disequilibrium error output pertanian yang positif menunjukkan jika terjadi lonjakan produksi pertanian di atas keseimbangan jangka panjangnya akan menjadi sumber shock yang meningkatkan permintaan modal di sektor non pertanian. Hal ini dimungkinkan karena output pertanian juga merupakan bahan baku dalam proses produksi output non pertanian (diindikasikan dari pengaruh disequilibrium error output pertanian terhadap output non pertanian yang positif walaupun secara statistik tidak siknifikan) sehingga kenaikan produksi pertanian juga akan menaikkan output non pertanian. Proses produksi yang menyebabkan kenaikan output non pertanian tersebut tentu saja membutuhkan barang modal yang lebih banyak sehingga dapat dimengerti mengapa lonjakan produksi pertanian tersebut juga akan meningkatkan permintaan modal non pertanian. Fenomena ini juga mengindikasikan bahwa perluasan investasi di sektor non pertanian sangat dipengaruhi oleh fluktuasi pertumbuhan output pertanian.

Ketiga, upah riil tenaga kerja sektor non pertanian dipengaruhi oleh dua sumber instabilitas yakni disequilibrium error permintaan modal non pertanian dan disequilibrium error permintaan tenaga kerja non pertanian. Koefisien disequilibrium error permintaan modal non pertanian yang negatif menunjukkan jika terjadi lonjakan permintaan modal di sektor non pertanian di atas keseimbangan jangka panjangnya akan menjadi sumber shock yang menurunkan upah riil. Hal ini dapat dimengerti kelebihan permintaan modal (investasi) akan cenderung mensubtitusi input produksi penting lainnya yakni tenaga kerja. Akibatnya terjadi penurunan permintaan tenaga kerja yang selanjutnya 
menyebabkkan penurunan upah tenaga kerja di sektor non pertanian tersebut (hal ini diindikasikan dari pengaruh disequilibrium error permintaan tenaga kerja non pertanian terhada upah ril tenaga kerja non pertanian yang positif).

Keempat, Ada empat disequilibrium error yang siknifikan mempengaruhi Harga material riil sektor non pertanian yakni disequilibrium error output non pertanian, disequilibrium error permintaan modal non pertanian dan disequilibrium error permintaan tenaga kerja non pertanian. Adapun bentuk hubungan keempat disequilibrium error tersebut terhadap harga material ril adalah sebagai berikut: 1) tanda koefisien disequilibrium error output non pertanian yang positif dan siknifikan mempengaruhi harga material ril menunjukkan jika terjadi lonjakan produksi non pertanian di atas keseimbangan jangka panjanganya akan menaikkan harga material di sektor non pertanian. Hal ini dapat dimengerti karena untuk menaikkan produksi akan membutuhkan input material yang lebih banyak pula, lonjakan permintaan input material ini lah yang selanjutnya menimbulkan lonjakan harga material sektor non pertanian. 2) Tanda koefisien yang positif dari disequilibrium error permintaan modal yang mempengaruhi harga material non pertanian menunjukkan jika terjadi lonjakan permintaan modal sektor non pertanian di atas keseimbangan jangka panjanganya akan menjadi sumber shock yang menaikkan harga material. Hal ini menunjukkan input modal dan input material satu sama lain saling komplementer untuk sektor non pertanian sehingga lonjakan permintaan modal akan menyebabkan shock yang meningkatkan permintaan input material yang selanjutnya meningkatkan harga input material tersebut.

Kelima, suku bunga adalah variabel yang paling banyak dipengaruhi oleh disequilibrium error baik yang berasal dari dalam blok produksi non pertanian maupun dari luarnya. Disequilibrium error yang berasal dari dalam blok produksi non pertanian yang berpengaruh siknifikan terhadap suku bunga adalah disequilibrium error penawaran output, disequilibrium error permintaan tenaga kerja dan disequilibrium error permintaan modal. Sedangkan disequilibrium error yang berasal dari luar blok produksi non pertanian yang berpengaruh siknifikan secara statistik adalah berasal dari blok permintaan aset finansial (disequilibrium error permintaan M2 dan disequilibrium error permintaan bond luar negeri) dan dari blok permintaan komoditas (disequilibrium error permintaan komoditas pertanian domestik dan disequilibrium error permintaan komoditas pertanian 
impor). Hal ini menunjukkan variabel suku bunga adalah variabel yang paling volatile terhadap guncangan ekonomi dari dalam maupun dari luar blok produksi non pertanian.

Keenam, jumlah disequlibrium error yang siknifikan mempengaruhi harga (input dan output non pertanian) ternyata lebih besar dibandingkan dengan jumlah disequilibrium error yang mempengaruhi kuantitas (produksi output dan permintaan input). Hal ini mengindikasikan instabilitas dalam blok produksi non pertanian ini lebih terkait oleh guncangan/ perubahan pada harga-harga (input ataupun output) dibanding karena guncangan/ perubahan kuantitas (output ataupun input).

\subsection{BLOK PERMINTAAN EKSPOR}

Tabel 8 menyajikan ringkasan koefisien dari disequilibrium error dari setiap persamaan dalam masing-masing blok ekonomi terhadap blok permintaan ekspor. Beberapa temuan empiris yang dapat dilihat dari tabel 8 tersebut adalah sebagai berikut:

Pertama, diantara permintaan ekspor, sumber guncangan terbanyak berasal dari permintaan ekspor pertanian. Hal ini mengindikasikan bahwa permintaan ekspor pertanian merupakan sumber utama instabilitas dari total ekspor. Hal ini karena walaupun kontribusi terhadap total ekspor menurun selama satu dekade terakhir (Irawan (2004), ekspor pertanian relatif tidak sestabil ekspor non pertanian sehingga menghasilkan ketidakpastian yang lebih besar.

Kedua, diantara blok-blok di luar blok permintaan ekspor, blok aset finansial dan blok permintaan komoditas adalah dua blok yang paling besar memberikan guncangan bagi blok permintaan ekspor. Hal ini mengindikasikan instabilitas ekspor berkaitan juga dengan konsumsi domestik dan kebijakan moneter.

Ketiga, Variabel permintaan ekspor non pertanian merupakan variabel yang paling banyak menerima eksternalitas yang berasal dari luar blok permintaan ekspor. Ini berarti permintaan ekspor non pertanian adalah variabel yang paling volatile dimana pergerakannya sangat dipengaruhi oleh gangguan dan perubahan yang berasal dari blok ekonomi lain. Hal juga menunjukkan kebijakan untuk memacu ekspor non pertanian merupakan kebijakan yang relatif kompleks dan sulit karena melibatkan sejumlah variabel ekonomi dari berbagai blok yang harus di intervensi. 


\subsection{GAMBARAN UMUM ANALISIS ERROR CORRECTION MODEL}

Berdasarkan diskusi dari seksi III.1 sampai III.5 penulis telah mencoba menganalisis semua kemungkinan keterkaitan antar 5 blok dalam model penelitian. Bagian ini akan merangkum poin-poin penting dari sejumlah diskusi pada bab III untuk mendapatkan gambaran umum tentang saling keterkaitan antar blok di dalam model penelitian.

Ringkasan hubungan saling keterkaitan dapat dilihat pada tabel 9 yang mana menunjukkan arti penting relatif masing-masing blok dalam arti kemampuan masingmasing blok menciptakan instabilitas didalam model perekonomian. Angka dalam kurung pada setiap sel mencerminkan posisi rangking dari blok yang bersangkutan didalam mentransmisikan disequilibrium errornya kepada blok penerima (dalam tabel berada dalam baris pertama), jadi angka (1) pada suatu sel blok menunjukkan blok yang bersangkutan berperan paling penting dalam menghasilkan dan menstransmisikan disequilibrium errornya kepada blok penerima, sebagai contoh pada baris kedua tabel 9, blok permintaan komoditas merupakan sumber instabilitas yang paling penting bagi blok permintaan komoditas dan blok produksi non pertanian tetapi bukan instabilitas penting bagi blok permintaan aset.

Tabel 9. Arti Penting Relatif masing-masing Blok sebagai Sumber Instabilitas

\begin{tabular}{|c|c|c|c|c|c|}
\hline \multirow[b]{2}{*}{ Sumber Instabilitas } & \multicolumn{5}{|c|}{ Penerima } \\
\hline & $\begin{array}{l}\text { Permintaan } \\
\text { Komoditas }\end{array}$ & $\begin{array}{l}\text { Permintaan } \\
\text { Aset }\end{array}$ & $\begin{array}{l}\text { Produksi } \\
\text { Pertanian }\end{array}$ & $\begin{array}{ll}\text { Produksi } & \text { Non } \\
\text { pertanian } & \\
\end{array}$ & $\begin{array}{l}\text { Permintaan } \\
\text { Ekpor }\end{array}$ \\
\hline $\begin{array}{l}\text { Permintaan } \\
\text { Komoditas }\end{array}$ & $15(1)$ & $2(4)$ & $0(5)$ & $5(2)$ & $3(3)$ \\
\hline Permintaan Aset & $12(1)$ & $12(1)$ & $4(3)$ & $3(4)$ & $9(2)$ \\
\hline Produksi Pertanian & $3(3)$ & $6(2)$ & $10(1)$ & $3(3)$ & $3(3)$ \\
\hline $\begin{array}{ll}\text { Produksi } & \text { Non } \\
\text { pertanian } & \end{array}$ & $5(2)$ & $5(2)$ & $3(3)$ & $11(1)$ & $1(4)$ \\
\hline Permintaan Ekpor & $2(2)$ & $2(2)$ & 0 & 0 & $4(1)$ \\
\hline
\end{tabular}

Keterangan:

1. Angka yang tidak dikurung menunjukkan jumlah disequilibrium error dari blok yang menjadi sumber instabilitas yang berpengaruh siknifikan terhadap variabel-variabel yang ada dalam blok penerimanya.

2. Angka di dalam ( ) menunjukkan peringkat blok yang bersangkutan dalam menghasilkan atau mentransmisi disequilibrium error terhadap blok penerima

Untuk blok permintaan aset, blok produksi pertanian dan produksi non pertanian merupakan sumber instabilitas terbesar. Blok permintaan aset juga memberikan umpan balik instabilitasnya yang kuat berturut-turut kepada blok permintaan komoditas dan blok 
pertanian. Fenomena ini menunjukkan distorsi terhadap pasar uang melalui kebijakan moneter akan secara efektif mempengaruhi konsumsi dan produksi pertanian.

Dibandingkan blok lainnya, blok permintaan aset dan blok produksi non pertanian merupakan sumber instabilitas utama bagi blok produksi pertanian. Tetapi pada saat yang bersamaan blok produksi pertanian merupakan sumber instabilitas penting bagi blok permintaan aset dan blok produksi pertanian. Hal ini mengindikasikan adanya interaksi dua arah yang kuat antara blok produksi pertanian dengan blok permintaan aset dan blok produksi non pertanian dibandingkan antara blok pertanian dengan blok lainnya.

Blok produksi non pertanian merupakan sumber instabilitas penting bagi blok permintaan komoditas dan pada yang bersamaan pula blok permintaan komoditas memberikan umpan balik disturbancesnya yang kuat bagi blok produksi non pertanian. Fenomena ini menunjukkan adanya interaksi dua arah yang kuat antara blok produksi non pertanian dan blok permintaan komoditas.

Adapun untuk blok permintaan ekspor, blok ini adalah blok yang paling rendah kemampuannya memberikan eksternalitas bagi blok lainnya, blok ini hanya memberikan eskternalitas bagi blok permintaan komoditas saja. Walaupun demikian di sisi lain blok ini banyak menerima eksternalitas dari blok lainnya. Blok yang paling besar memberikan ekternalitas bagi blok permintaan ekspor berturut-turut berdasarkan rankingnya adalah blok permintaan aset, permintaan ekspor, produksi pertanian dan blok permintaan komoditas.

Untuk mendapatkan kesimpulan yang labih tajam tentang arti penting masingmasing blok dalam perekonomian, maka kita perlu melihat posisi masing-masing blok sebagai sumber atau penerima instabilitas. Tabel 10 merangkum peringkat masing-masing blok dimana angka 1 mencerminkan peringkat tertinggi sedangkan angka 5 mencerminkan peringkat terendah. Jika dilihat dari tabel 10 tampak bahwa blok yang paling tinggi kemampuanya menstransmisi instabilitas ke blok lain sekaligus sebagai penerima yang penting bagi instabilitas atau disturbances blok lain berturut-turut adalah blok permintaan komoditas dan blok permintaan aset pada posisi teratas dikuti oleh blok produksi non pertanian dan blok produksi pertanian. Sedangkan yang paling rendah kemampuan mentransmisi instabilitas ke blok lain adalah blok permintaan ekspor. 
Tabel 10. Tingkat Kemampuan Blok sebagai Sumber dan Penerima Eksternalitas (disturbances)

\begin{tabular}{|l|c|c|}
\hline Blok & $\begin{array}{c}\text { Sebagai Sumber } \\
\text { Eksternalitas } \\
\text { (disturbances) }\end{array}$ & $\begin{array}{c}\text { Sebagai Penerima } \\
\text { Eksternalitas } \\
\text { (disturbances) }\end{array}$ \\
\hline Permintaan Komoditas & 2 & 1 \\
\hline Permintaan Aset & 1 & 2 \\
\hline Produksi Pertanian & 2 & 5 \\
\hline Produksi non Pertanian & 2 & 3 \\
\hline Permintaan Eskpor & 3 & 4 \\
\hline
\end{tabular}

Keterangan: Angka 1 menunjukkan peringkat tertinggi sedangkan angka 5 adalah peringkat terendah

Terdapat paling tidak 2 implikasi atas temuan ini, (i) pemerintah seharusnya berkonsentrasi pada permintaan komoditas dan permintaan aset untuk menstabilisasi perekonomian karena kedua blok tersebut merupakan kontributor penting fluktuasi ekonomi, (ii) pemerintah seharusnya melakukan kebijakan stabilisasi yang integratif terhadap sumber-sumber disequilibrium kedua blok tersebut karena menurut model penelitian ini setiap aksi kebijakan yang berkaitan dengan salah satu blok diatas akan menjadi shock yang selanjutnya mampu menjadi sumber destabilisasi ekonomi. 


\section{KESIMPULAN DAN IMPLIKASI KEBIJAKAN}

Adapun kesimpulan yang dapat ditarik berdasarkan analisis perilaku instabilitas perekonomian Indonesia dalam jangka pendek adalah sebagai berikut:

1. Blok yang paling tinggi kemampuannya menstransmisi instabilitas ke blok lain berturut-turut blok permintaan aset pada posisi teratas dikuti oleh blok permintaan komoditas, blok produksi non pertanian dan blok produksi pertanian. Sedangkan yang paling rendah kemampuan menstransmisi instabilitas ke blok lain adalah blok permintaan ekspor. Temuan ini menunjukkan pemerintah seharusnya berkonsentrasi pada blok permintaan komoditas dan permintaan aset untuk menstabilisasi perekonomian karena kedua blok tersebut merupakan kontributor penting fluktuasi ekonomi, pemerintah seharusnya melakukan kebijakan stabilisasi yang integratif terhadap sumber-sumber disequilibrium kedua blok tersebut karena menurut model penelitian ini setiap aksi kebijakan yang berkaitan dengan salah satu blok diatas akan menjadi shock yang selanjutnya mampu menjadi sumber destabilisasi ekonomi.

2. Untuk menstabilisasi permintaan komoditas, dibutuhkan pula kestabilan pasar aset finansial, karena blok aset finansial merupakan blok yang paling besar kontribusi instabilitas ke blok permintaan komoditas. Dan diantara permintaan aset finansial tersebut permintaan uang (M2) berperan penting dalam menentukan instabilitas blok permintaan komoditas. Diketahui pula disequilibrium error permintaan uang ini berpengaruh siknifikan terhadap harga-harga komoditas, pertumbuhan uang yang stabil diharapkan akan mereduksi volatilitas harga-harga komoditas. Pertumbuhan uang yang stabil memang merupakan proposisi utama dari kalangan mazhab monetarist untuk menghasilkan kebijakan moneter yang efektif.

3. Blok permintaan aset finansial dan blok produksi non pertanian adalah sumber eksternalitas (spillover) terhadap blok produksi pertanian. Walaupun demikian yang paling kuat eksternalitasnya adalah blok permintaan aset finasial. Hal ini ditunjukkan dengan koefisien disequilibrium error permintaan M2, bond domestik dan bond luar negeri berpengaruh siknifikan secara statistik terhadap produksi pertanian, sedangkan blok produksi non pertanian hanya disequilibrium error produksi dan disequilibrium error permintaan modal saja yang berpengaruh siknifikan masing-masing terhadap variabel permintaan modal pertanian dan 
variabel produksi pertanian. Hal ini menunjukkan blok produksi pertanian relatif lebih volatile terhadap gangguan (disturbance) dari blok permintaan aset finansial dibanding disturbance ekonomi lainnya.

4. Jumlah disequilibrium error yang siknifikan mempengaruhi harga (input dan output pertanian dan non pertanian) ternyata lebih besar dibandingkan dengan jumlah disequilibrium error yang mempengaruhi kuantitas (produksi output dan permintaan input). Hal ini mengindikasikan instabilitas dalam blok produksi pertanian dan non pertanian ini lebih terkait oleh guncangan/ perubahan pada harga-harga (input ataupun output) dibanding karena guncangan/ perubahan kuantitas (output ataupun input). 


\section{DAFTAR PUSTAKA}

Beck, M and P. Winker. 2004. Modeling Spillover and Feedback of International Trade in a Disequilibrium Error Framework. Economic Modeling, 21:445-470.

Feridhanusetyawan, T and M. Pangestu. 2004. Indonesia in Crisis: A Macroeconomic Persepective.Economic Working Paper Series. http://www.csis.or.id/paper/wpe074

Irawan, A. 2005. Analisis Perilaku Instabilitas, Pergerakan Harga, Employment dan Investasi di dalam Sektor Pertanian Indonesia: Aplikasi Vector Error Correction Model. Buletin Ekonomi Moneter dan Perbankan 8(3):79-115

Irawan, A. 2004. Komoditas Pertanian Indonesia. Target Ekspor dan Hambatan Sisi Permintaan dan Penawaran. Agrimedia 9 (2):45-50.

Sugema, I. 1992. The Dynamic of Macroeconomy-Trade-Agriculture Linkages in The Australian Economy: An Application of Error Correction Model to Cointegrated Relation Ship. The University of New England. Thesis S2. Department of Agricultural Economic and Business Management, New England.

Supriana, T. 2004. Dampak Guncangan Struktural terhadap Fluktuasi Ekonomimakro Indonesia: Suatu Kajian Business Cycle Dari Sisi Permintaan. Disertasi S3 Sekolah Pascasarjana, Institut Pertanian Bogor, Bogor.

Zaini, A. 2003. Peranan Sektor Pertanian Sebelum dan Pada Masa Krisis Ekonomi di Indonesia: Pendekatan Sistem Neraca Sosial Ekonomi. Tesis S2 Sekolah Pascasarjana, Institut Pertanian Bogor, Bogor. 


\section{Lampiran 1. Historis Fenomena Ekonomi Penting di Indonesia}

Tabel 1. Fenomena-fenomena Ekonomi Penting sebagai Sumber Instabilitas Ekonomi Indonesia Menjelang dan Saat Krisis Ekonomi

\begin{tabular}{|c|c|c|}
\hline Periode & Fenomena Penting & Faktor Penyebab \\
\hline Juni - Juli 1997 & $\begin{array}{l}\text { Terjadinya capital outflow yang } \\
\text { masif dari kawasan Asia Tenggara } \\
\text { termasuk Indonesia }\end{array}$ & $\begin{array}{l}\text { Kolapsnya ekonomi Thailand yang } \\
\text { menyebabkan kerentan- } \\
\text { an ekonomi kawasan, beru- } \\
\text { bahnya persepsi dari investor } \\
\text { internasional, hilangnya ke- } \\
\text { percayaan terhadap prospek ASEAN } \\
\text { sebagai macan Asia }\end{array}$ \\
\hline $\begin{array}{l}\text { Agustus-September } \\
1997\end{array}$ & $\begin{array}{l}\text {-Mulai terjadi turunnya nilai } \\
\text { tukar rupiah terhadap dolar } \\
\text { Amerika Serikat } \\
\text {-Mulai terjadi kenaikan suku bunga } \\
\text {-Mulai terjadi kepanikan di pasar } \\
\text { finansial }\end{array}$ & $\begin{array}{l}\text {-Serangan spekulator pasar } \\
\text { uang terhadap rupiah } \\
\text {-Kenaikan suku bunga } \\
\text { Sertifikat Bank Indonesia } \\
\text { (SBI) } \\
\text {-Kebijakan moneter yang } \\
\text { sangat ketat tanpa ada usaha } \\
\text { untuk memperbaiki meng- } \\
\text { angkat ekspetasi pasar }\end{array}$ \\
\hline $\begin{array}{l}\text { Oktober-Nopember } \\
1997\end{array}$ & $\begin{array}{l}\text {-terjadinya penarikan dana oleh } \\
\text { masyarakat secara masif baik dari } \\
\text { bank yang sehat maupun yang sakit } \\
\text {-Hilangnya keyakinan bahwa } \\
\text { pemerintah Soeharto saat itu akan } \\
\text { mampu menangani krisis }\end{array}$ & $\begin{array}{l}\text { - Likuidasi bank berdasarkan } \\
\text { nasehat IMF }\end{array}$ \\
\hline $\begin{array}{l}\text { Desember } 1997- \\
\text { Januari } 1998\end{array}$ & $\begin{array}{l}\text { MONETER: } \\
\text {-Rupiah turun lebih lanjut } \\
\text {-capital outflow yang masif tetap } \\
\text { terjadi termasuk terjadinya usaha } \\
\text { penyelundupan rupiah ke luar negeri } \\
\text {-Inflasi mulai meninggi } \\
\text {-Sektor perbankan mulai kolaps } \\
\text { menyusul L/C yang dikeluarkan } \\
\text { perbankan nasional ditolak oleh } \\
\text { kalangan internasional } \\
\text { SEKTOR RIIL: } \\
\text {-Terjadi kepanikan investor } \\
\text { domestic khususnya para } \\
\text { pengusaha Cina } \\
\text {-Berbondong-bondong ma- } \\
\text { syarakat memborong bahan pangan } \\
\text { (food rush) }\end{array}$ & $\begin{array}{l}\text {-Terjadi kenaikan permin- } \\
\text { taan yang besar terhadap } \\
\text { dolar untuk pembayaran } \\
\text { hutang } \\
\text {-Suplai uang tidak bisa } \\
\text { dikontrol } \\
\text {-Publik kehilangan keperca- } \\
\text { yaan terhadap perbankan } \\
\text { domestik } \\
\text {-Bank luar negeri tidak lagi } \\
\text { memiliki trust terhadap bank } \\
\text { domestik } \\
\text {-Terjadinya peningkatan } \\
\text { kerusuhan anti Cina } \\
\text { disejumlah kota di Jawa } \\
\text {-Publik menduga akan } \\
\text { terjadi kesulitan untuk } \\
\text { mendapatkan pangan }\end{array}$ \\
\hline
\end{tabular}

Sumber: Feridhanusetyawan and Pangestu (2004) 
Tabel 1. Lanjutan

\begin{tabular}{|c|c|c|}
\hline Periode & Fenomena Penting & Faktor Penyebab \\
\hline $\begin{array}{l}\text { Desember } 1997- \\
\text { Januari } 1998\end{array}$ & $\begin{array}{l}\text { SOSIAL-POLITIK } \\
\text {-Hilangnya kepercayaan ter- } \\
\text { hadap rezim Soeharto } \\
\text {-Situasi politik menjadi tidak } \\
\text { menentu }\end{array}$ & $\begin{array}{l}\text {-Kegagalan pemerintah me- } \\
\text { ngatasi masalah-masalah } \\
\text { ekonomi yang muncul }\end{array}$ \\
\hline $\begin{array}{l}\text { Juni - Desember } \\
1998\end{array}$ & $\begin{array}{l}\text { MONETER: } \\
\text {-Suku bunga naik secara ekstrem } \\
\text {-Inflasi tinggi berlanjut } \\
\text {-Perbankan kolaps } \\
\text { SEKTOR RIIL: } \\
\text { Sejumlah bentuk kontraksi ekonomi } \\
\text { seperti: } \\
\text {-Indeks harga Saham (stock market } \\
\text { index) jatuh } \\
\text {-sektor riil secara mendasar telah } \\
\text { kolaps } \\
\text { SOSIAL POLITIK: } \\
\text {-Secara menyeluruh terjadinya } \\
\text { ketidakpastian yang besar terhadap } \\
\text { ekonomi, sosial dan politik }\end{array}$ & $\begin{array}{l}\text {-Kebijakan moneter yang } \\
\text { sangat ketat untuk } \\
\text { mengontrol suplai uang } \\
\text {-Tidak ada resolusi terhadap } \\
\text { restrukturisasi perbankan } \\
\text {-Kerusuhan yang berlanjut } \\
\text { pada sejumlah tempat di } \\
\text { Indonesia }\end{array}$ \\
\hline
\end{tabular}

Sumber: Feridhanusetyawan and Pangestu (2004) 


\section{Lampiran 2. Variabel, Data dan Sumbernya}

Tabel 3. Variabel-variabel dan data yang dalam Model Penelitian

\begin{tabular}{|c|c|c|c|}
\hline \multirow[t]{2}{*}{ Blok } & \multicolumn{2}{|c|}{ Variabel } & \multirow[t]{2}{*}{ Data } \\
\hline & Simbol & Keterangan simbol & \\
\hline \multirow{10}{*}{$\begin{array}{l}\text { BLOK } \\
\text { PERMINTA- } \\
\text { AN } \\
\text { KOMODI-TAS }\end{array}$} & LC_BINA & $\begin{array}{l}\text { Log nilai Import } \\
\text { Pertanian }\end{array}$ & $\begin{array}{l}\text { Sumber: CEIC data Company } \\
\text { limited } \\
\text { (ribu USA \$) }\end{array}$ \\
\hline & LCBIN_N1 & $\begin{array}{l}\text { Log nilai import non } \\
\text { pertanian }\end{array}$ & $\begin{array}{l}\text { Sumber: CEIC data Company } \\
\text { limited } \\
\text { (ribu USA \$) }\end{array}$ \\
\hline & $\mathrm{LCA}$ & $\begin{array}{l}\text { Log total Permintaan } \\
\text { komoditas Pertanian }\end{array}$ & $\begin{array}{l}\text { Dihitung PDB pertanian - Ekspor } \\
\text { Pertanian (dalam milyar rupiah) }\end{array}$ \\
\hline & $\mathrm{LCN}$ & $\begin{array}{l}\text { Log total Permintaan } \\
\text { komoditas non pertanian }\end{array}$ & $\begin{array}{l}\text { Dihitung; PDB pertanian - Ekspor } \\
\text { non pertanian (milyar Rupiah) }\end{array}$ \\
\hline & $\mathrm{LP}_{\mathrm{A}}$ & $\begin{array}{l}\text { Log Harga output } \\
\text { pertanian. }\end{array}$ & $\begin{array}{l}\text { Data harga output didekati dengan } \\
\text { Indeks harga pedagang besar untuk } \\
\text { pertanian }(1983=100) \text {. Sumber } \\
\text { CEIC data Company Limited }\end{array}$ \\
\hline & $\mathrm{LP}_{\mathrm{N}}$ & $\begin{array}{l}\text { Log Harga Ourput } \\
\text { Industri }\end{array}$ & $\begin{array}{l}\text { Indeks Harga Pedagang Besar } \\
\text { Manufaktur } 1983=100\end{array}$ \\
\hline & LREER & $\begin{array}{l}\text { Log Real Effective } \\
\text { Exchange Rate }\end{array}$ & $\begin{array}{l}\text { Sumber: Bagian Analisis dan } \\
\text { Perencanaan Kebijakan (APK BI) }\end{array}$ \\
\hline & LX & $\begin{array}{l}\text { Log Pengeluaran } \\
\text { konsumsi rumahtangga } \\
\text { domestik }\end{array}$ & $\begin{array}{l}\text { Pengeluaran Konsumsi rumahtangga } \\
\text { (milyar rupiah). Sumber: } \\
\text { International Financial Statistic } \\
\text { (IFS) }\end{array}$ \\
\hline & LPBINA & $\begin{array}{l}\text { Log harga Impor } \\
\text { komoditas pertanian }\end{array}$ & $\begin{array}{l}\text { Didekati dengan Indeks harga } \\
\text { Pedagang besar non migas } \\
(1983=100) \text { sumber CEIC data } \\
\text { Company Limited }\end{array}$ \\
\hline & LPBINN1 & $\begin{array}{l}\text { Log harga Impor } \\
\text { Komoditas non pertanian }\end{array}$ & $\begin{array}{l}\text { Didekati dengan indeks harga } \\
\text { pedagang besar Impor }(1983=100)\end{array}$ \\
\hline
\end{tabular}


Tabel 3. Lanjutan

\begin{tabular}{|c|c|c|c|}
\hline \multirow{2}{*}{$\begin{array}{l}\mathbf{B} \\
\mathbf{L} \\
\mathbf{O} \\
\mathbf{K}\end{array}$} & \multicolumn{2}{|r|}{ Variabel } & \multirow[t]{2}{*}{ Data } \\
\hline & Simbol & $\begin{array}{c}\text { Keterangan } \\
\text { simbol }\end{array}$ & \\
\hline \multirow{7}{*}{$\begin{array}{l}\text { P } \\
\text { R } \\
\text { M } \\
\text { M } \\
\text { I } \\
\mathrm{N} \\
\mathrm{T} \\
\mathrm{A} \\
\mathrm{A} \\
\mathrm{N}\end{array}$} & LM2 & Log M2 & M2. Sumber; Bagian Studi Sektor Riil Bank Indonesia \\
\hline & LPM & $\begin{array}{l}\text { Log implicit price } \\
\text { for holding money } \\
\text { (Harga Implisit } \\
\text { Pemegangan uang) }\end{array}$ & 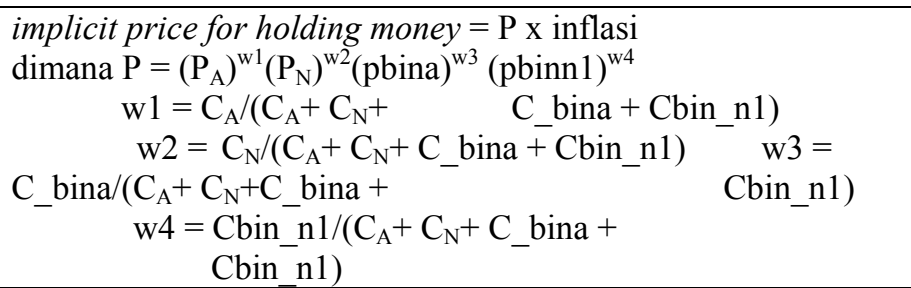 \\
\hline & LPB & $\begin{array}{l}\text { log implicit price } \\
\text { for domestic bonds } \\
\text { (Harga Implisit } \\
\text { Pemegangan Surat } \\
\text { Berharga } \\
\text { Domestik) }\end{array}$ & 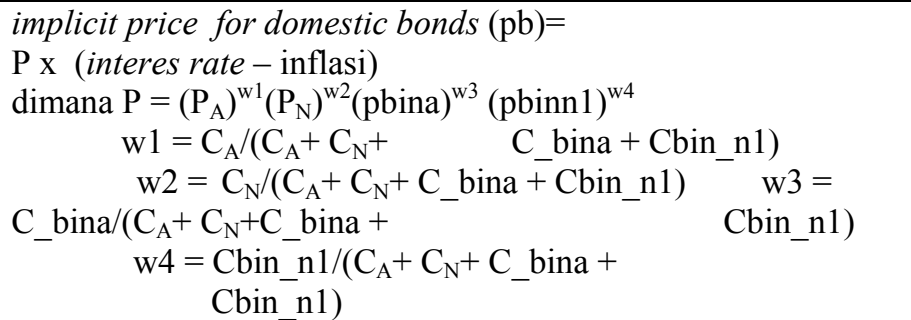 \\
\hline & LPBIN & $\begin{array}{l}\text { log implicit price } \\
\text { for foreign bond } \\
\text { (Harga Implisit } \\
\text { Pemegangan Surat } \\
\text { Berharga Luar } \\
\text { Negeri }\end{array}$ & 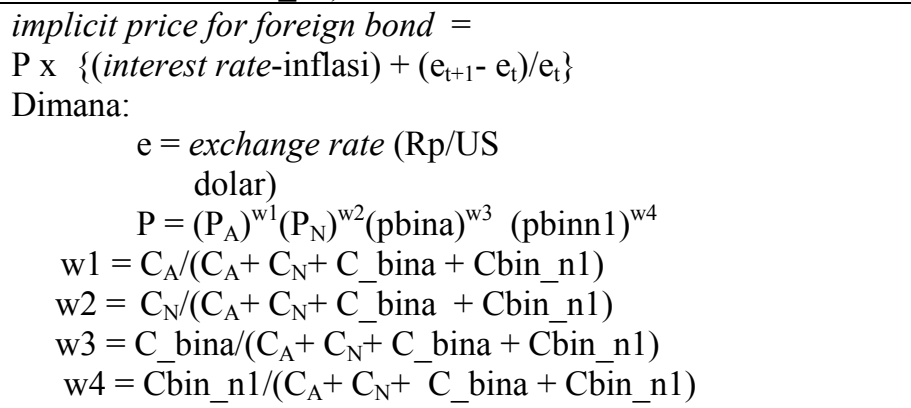 \\
\hline & LW & $\begin{array}{l}\text { Log Nominal } \\
\text { Wealth }\end{array}$ & $\begin{array}{l}\text { Nominal Wealth }(\mathrm{W})=(\mathrm{M} 2+\text { Surat Berharga Domestik } \\
(\text { domestic bond })+\text { Surat Berharga Luar Negeri (foreign bond } \\
\text { /foreign assets })\end{array}$ \\
\hline & LB & $\begin{array}{l}\text { Log Surat } \\
\text { Berharga (bond) } \\
\text { domestik }\end{array}$ & $\begin{array}{l}\text { Klaim terhadap Pemerintah Pusat dan Sektor Swasta (Claims on } \\
\text { Central Govt. and Private Sector) dideflasi dengan harga } \\
\text { implisit dari Surat Berharga (bond) domestik. Sumber: } \\
\text { International Financial Statistic (IFS) }\end{array}$ \\
\hline & LBBIN & $\begin{array}{l}\text { Log bond Luar } \\
\text { negeri }\end{array}$ & $\begin{array}{l}\text { Aset Luar Negeri (Foreign Assets) dideflasi dengan Harga } \\
\text { Implisit dari Surat Berharga (bond) luar negeri }\end{array}$ \\
\hline
\end{tabular}


Tabel 3. Lanjutan

\begin{tabular}{|c|c|c|c|}
\hline \multirow[t]{2}{*}{ Blok } & \multicolumn{2}{|r|}{ Variabel } & \multirow[t]{2}{*}{ Data } \\
\hline & Simbol & Keterangan simbol & \\
\hline \multirow{7}{*}{$\begin{array}{l}\text { PRO- } \\
\text { DUK-SI } \\
\text { PER- } \\
\text { TANI- } \\
\text { AN }\end{array}$} & $\mathrm{LY}_{\mathrm{A}}$ & Log PDB Pertanian. & $\begin{array}{l}\text { PDB Pertanian adalah jumlah PDB tanaman } \\
\text { pangan, PDB tanaman perkebunan, PDB } \\
\text { peternakan, PDB hutan, PDB Perikanan. } \\
\text { Sumber: Studi Sektor Riil Bank Indonesia }\end{array}$ \\
\hline & $\mathrm{r}$ & Harga Modal (suku bunga) & $\begin{array}{l}\text { Suku Bunga Sertifikat Bank Indonesia (SBI) } 30 \\
\text { hari (\% per tahun) ( Bank Indonesia } \\
\text { Certificates Rate: Auction Target: } 30 \text { days (\% } \\
\text { pa)). Sumber: Studi Sektor Riil Bank } \\
\text { Indonesia }\end{array}$ \\
\hline & $\mathrm{LP}_{\mathrm{A}}$ & Log Harga output pertanian. & $\begin{array}{l}\text { Data harga output didekati dengan Indeks } \\
\text { harga pedagang besar untuk pertanian } \\
(1983=100) . \text { Sumber: CEIC data Company } \\
\text { Limited }\end{array}$ \\
\hline & $\mathrm{LW}_{\mathrm{A}}$ & $\begin{array}{l}\text { Log Upah Tenaga Kerja } \\
\text { Sektor Pertanian }\end{array}$ & $\begin{array}{l}\text { Satuan (Rp per bulan). Sumber: Studi Sektor } \\
\text { Riil Bank Indonesia }\end{array}$ \\
\hline & $\mathrm{LPM}_{\mathrm{a}}$ & $\begin{array}{l}\text { Log Harga Material yang } \\
\text { dibayar petani }\end{array}$ & $1983=100$. Sumber: Indikator Ekonomi BPS \\
\hline & $\mathrm{LK}_{\mathrm{A}}$ & Log Kredit Investasi Pertanian & Sumber: Studi Sektor Riil BI \\
\hline & $\mathrm{LL}_{\mathrm{A}}$ & $\begin{array}{l}\text { Log jumlah Tenaga Kerja di } \\
\text { Sektor pertanian }\end{array}$ & Sumber: Studi Sektor Riil BI \\
\hline \multirow{7}{*}{$\begin{array}{l}\text { PRO- } \\
\text { DUK-SI } \\
\text { NON } \\
\text { PER- } \\
\text { TANI- } \\
\text { AN }\end{array}$} & $\mathrm{LY}_{\mathrm{N}}$ & $\begin{array}{l}\text { Log Produksi non Pertanian } \\
\text { (Industri) }\end{array}$ & $\begin{array}{l}\text { PDB Industri (milyar Rupiah). Sumber: CEIC } \\
\text { data Company Limited }\end{array}$ \\
\hline & $\mathrm{LP}_{\mathrm{N}}$ & Log Harga Ourput Industri & $\begin{array}{l}\text { Indeks Harga Pedagang Besar Manufaktur } \\
1983=100\end{array}$ \\
\hline & $\mathrm{LW}_{\mathrm{N}}$ & $\begin{array}{l}\text { Log Upah tenaga Kerja sektor } \\
\text { Industri }\end{array}$ & $\begin{array}{l}\text { Satuan (Rp per bulan). Sumber: Studi Sektor } \\
\text { Riil Bank Indonesia }\end{array}$ \\
\hline & $\mathrm{LPM}_{\mathrm{N}}$ & $\begin{array}{l}\text { Log harga material di produksi } \\
\text { non pertanian }\end{array}$ & $\begin{array}{l}\text { Indeks harga Pedagang Besar material } \\
\text { konstruksi } 1983=100 . \text { Sumber CEIC data } \\
\text { Company Limited }\end{array}$ \\
\hline & $\mathrm{r}$ & Harga Modal (suku bunga) & $\begin{array}{l}\text { Suku Bunga Sertifikat Bank Indonesia (SBI) } 30 \\
\text { hari (\% per tahun) ( Bank Indonesia } \\
\text { Certificates Rate: Auction Target: } 30 \text { days (\% } \\
\text { pa)). Sumber: Studi Sektor Riil Bank } \\
\text { Indonesia }\end{array}$ \\
\hline & $\mathrm{LK}_{\mathrm{N}}$ & Log Modal sektor non pertanian & $\begin{array}{l}\text { Dihitung: Kredit Investasi total - Kredit } \\
\text { Investasi pertanian. Sumber: Studi Sektor Riil } \\
\text { BI }\end{array}$ \\
\hline & $\mathrm{LW}_{\mathrm{N}}$ & $\begin{array}{l}\text { Log Jumlah Tenaga Kerja di } \\
\text { Sektor industri }\end{array}$ & $\begin{array}{l}\text { Satuan (Rp per bulan). Sumber: Studi Sektor } \\
\text { Riil Bank Indonesia }\end{array}$ \\
\hline
\end{tabular}


Tabel 3. Lanjutan

\begin{tabular}{|c|c|c|c|}
\hline \multirow[t]{2}{*}{ Blok } & \multicolumn{2}{|c|}{ Variabel } & \multirow[t]{2}{*}{ Data } \\
\hline & Simbol & Keterangan simbol & \\
\hline \multirow{6}{*}{$\begin{array}{l}\text { EKSPOR } \\
\text { KOMODITAS }\end{array}$} & LC_A & Log Ekspor Pertanian & $\begin{array}{l}\text { Satuan: \$ USA jutaan Sumber;CEIC } \\
\text { data Company Limited }\end{array}$ \\
\hline & LC_N & Log Ekpor non Pertanian & $\begin{array}{l}\text { Satuan: \$ USA jutaan. Sumber: CEIC } \\
\text { data Company Limited }\end{array}$ \\
\hline & LP_N & $\begin{array}{l}\text { Log Indeks harga ekspor } \\
\text { non pertanian }\end{array}$ & $\begin{array}{l}\text { Didekati dengan indeks Harga ekspor } \\
\text { minyak dan gas }(1983=100) \text {. Sumber: } \\
\text { CEIC data Company Limited }\end{array}$ \\
\hline & LP_A & $\begin{array}{l}\text { Log Indeks Harga ekspor } \\
\text { produk pertanian }\end{array}$ & $\begin{array}{l}\text { Didekati dengan indeks Harga ekspor } \\
\text { non migas }(1983=100) \text {. Sumber: CEIC } \\
\text { data Company Limited }\end{array}$ \\
\hline & 1X_bin & Log Belanja konsumsi dunia & $\begin{array}{l}\text { Didekati dengan penjumlahan } \\
\text { Pengeluaran Konsumsi rumahtangga } \\
\text { Amerika Serikat, Jepang, Inggris, } \\
\text { Australia Hongkong dan Kanada. } \\
\text { Sumber: International Financial } \\
\text { Statistic (IFS) } \\
\end{array}$ \\
\hline & LREER & $\begin{array}{l}\text { Log Indeks Real Effective } \\
\text { Exchange Rate }\end{array}$ & $\begin{array}{l}\text { Indeks REER dihitung dengan } \\
\text { menggunakan sekeranjang mata uang } \\
\text { dan laju inflasi dari negara mitra } \\
\text { dagang utama (Amerika Serikat, } \\
\text { Jepang, Korea Selatan, Singapura, } \\
\text { Jerman, Taiwan, RRC dan Belanda) } \\
\text { dengan memperhitungkan proporsi } \\
\text { perdagangan (ekspor) dan atau impor } \\
\text { antara Indonesia dengan Negara- } \\
\text { negara tersebut. Sumber: Bagian } \\
\text { Analisis dan Perencanaan Kebijakan } \\
\text { (APK ) BI }\end{array}$ \\
\hline
\end{tabular}




\section{Lampiran 3. Hasil Estimasi Model}

Tabel 4. Koefisien Estimasi dari masing-masing Disequilibrium Error masing-masing Persamaan pada Setiap Blok terhadap Blok

Permintaan Komoditas

\begin{tabular}{|c|c|c|c|c|c|c|c|c|c|c|c|}
\hline Blok & $\begin{array}{l}\text { Sumber Disequ- } \\
\text { ilibrium Error }\end{array}$ & $\begin{array}{c}\text { Permintaan } \\
\text { Pertanian } \\
\text { D(LCA) }\end{array}$ & $\begin{array}{l}\text { Permintaan non } \\
\text { Pertanian } \\
\text { D(LCN) }\end{array}$ & $\begin{array}{c}\text { Permintaan } \\
\text { Pertanian Impor } \\
\text { D(LC_BINA) }\end{array}$ & $\begin{array}{c}\text { Permintaan non } \\
\text { Pertanian Impor } \\
\text { D(LCBIN_N1) }\end{array}$ & \begin{tabular}{|c|} 
Harga \\
Pertani-an \\
DomestikD \\
(LPA) \\
\end{tabular} & $\begin{array}{c}\text { Harga non } \\
\text { Pertanian } \\
\text { Domestik } \\
\text { D(LPN) } \\
\end{array}$ & $\begin{array}{l}\text { Harga Impor } \\
\text { Pertanian } \\
\text { D(LPBINA) }\end{array}$ & $\begin{array}{c}\text { Harga Impor } \\
\text { non Pertanian } \\
\text { D(LPBINN1) }\end{array}$ & $\begin{array}{c}\text { Real Effective } \\
\text { Exchange } \\
\text { rate } \\
\text { D(LREER) }\end{array}$ & $\begin{array}{l}\text { Penge- } \\
\text { luaran } \\
\text { Total } \\
\mathrm{D}(\mathrm{LX}) \\
\end{array}$ \\
\hline $\begin{array}{l}\mathrm{P} \\
\mathrm{E} \\
\mathrm{R} \\
\mathrm{M}\end{array}$ & \begin{tabular}{|c} 
Permintaan \\
Komoditas Pertanian \\
Domestik (E_CA(- \\
1))
\end{tabular} & $\begin{array}{c}-0.571 \\
(0.229) \\
{[-2.494]}\end{array}$ & $\begin{array}{r}-0.642548 \\
(0.31242) \\
{[-2.05669]}\end{array}$ & $\begin{array}{r}3.120617 \\
(1.31227) \\
{[2.37803]}\end{array}$ & $\begin{array}{r}3.770508 \\
(0.69837) \\
{[5.39899]}\end{array}$ & \begin{tabular}{|c|}
-0.372 \\
$(0.176)$ \\
{$[-2.115]$}
\end{tabular} & $\begin{array}{r}-0.06308 \\
(0.0873) \\
{[-0.7296]}\end{array}$ & $\begin{array}{r}0.739730 \\
(0.32228) \\
{[2.29530]}\end{array}$ & $\begin{array}{r}0.633378 \\
(0.31163) \\
{[2.03246]}\end{array}$ & $\begin{array}{c}-1.47 \\
(0.54) \\
{[-2.69]}\end{array}$ & $\begin{array}{r}-0.249 \\
(0.23) \\
{[-1.04]}\end{array}$ \\
\hline $\begin{array}{l}1 \\
\mathrm{~N} \\
\mathrm{~T} \\
\mathrm{~A} \\
\mathrm{~N}\end{array}$ & $\begin{array}{c}\text { Permintaan } \\
\text { Komoditas non } \\
\text { Pertanian Domestik } \\
(\text { E_CN(-1)) }\end{array}$ & $\begin{array}{c}0.094 \\
(0.150) \\
{[0.629]}\end{array}$ & $\begin{array}{r}0.154359 \\
(0.20490) \\
{[0.75333]}\end{array}$ & $\begin{array}{r}-1.763193 \\
(0.86066) \\
{[-2.04864]}\end{array}$ & $\begin{array}{r}-3.373659 \\
(0.45804) \\
{[-7.36550]}\end{array}$ & $\begin{array}{c}0.366 \\
(0.115) \\
{[3.175]}\end{array}$ & $\begin{array}{r}0.18152 \\
(0.0572) \\
{[3.1696]}\end{array}$ & $\begin{array}{r}0.208888 \\
(0.21137) \\
{[0.98825]}\end{array}$ & $\begin{array}{r}0.295262 \\
(0.20439) \\
{[1.44462]}\end{array}$ & $\begin{array}{c}0.81 \\
(0.35) \\
{[2.26]}\end{array}$ & $\begin{array}{c}0.242 \\
(0.155) \\
{[1.55]}\end{array}$ \\
\hline $\begin{array}{l}\mathrm{K} \\
\mathrm{O} \\
\mathrm{M} \\
\mathrm{O} \\
\mathrm{D}\end{array}$ & $\begin{array}{c}\text { Permintaan } \\
\text { Komoditas Pertanian } \\
\text { Impor (E_C_BINA(- } \\
\overline{1}) \text { ) }\end{array}$ & $\begin{array}{c}0.025 \\
(0.025) \\
{[0.99]}\end{array}$ & $\begin{array}{r}0.006603 \\
(0.03501) \\
{[0.18860]}\end{array}$ & $\begin{array}{r}-0.869603 \\
(0.14705) \\
{[-5.91356]}\end{array}$ & $\begin{array}{c}0.089598 \\
(0.07826) \\
{[1.14488]}\end{array}$ & $\begin{array}{l}0.036 \\
(0.019) \\
{[1.83]}\end{array}$ & $\begin{array}{r}0.00997 \\
(0.0097) \\
{[1.0195]}\end{array}$ & $\begin{array}{r}0.036893 \\
(0.03611) \\
{[1.02155]}\end{array}$ & $\begin{array}{r}0.055917 \\
(0.03492) \\
{[1.60121]}\end{array}$ & $\begin{array}{l}-0.136 \\
(0.061) \\
{[-2.22]}\end{array}$ & $\begin{array}{l}0.004 \\
(0.02) \\
{[0.15]}\end{array}$ \\
\hline $\begin{array}{l}\mathrm{T} \\
\mathrm{A} \\
\mathrm{S}\end{array}$ & $\begin{array}{c}\text { Permintaan } \\
\text { Komoditas non } \\
\text { Pertanian Impor } \\
\text { E_C_BINN1(-1)) }\end{array}$ & $\begin{array}{c}0.019 \\
(0.051) \\
{[0.36]}\end{array}$ & $\begin{array}{r}0.075257 \\
(0.07038) \\
{[1.06935]}\end{array}$ & $\begin{array}{r}-0.131776 \\
(0.29561) \\
{[-0.44578]}\end{array}$ & $\begin{array}{r}-1.272392 \\
(0.15732) \\
{[-8.08802]}\end{array}$ & $\begin{array}{c}0.093 \\
(0.039) \\
{[2.36]}\end{array}$ & $\begin{array}{l}0.05007 \\
(0.0196) \\
{[2.5457]}\end{array}$ & $\begin{array}{c}0.071555 \\
(0.07260) \\
{[0.98564]}\end{array}$ & $\begin{array}{r}0.069189 \\
(0.07020) \\
{[0.98561]}\end{array}$ & $\begin{array}{c}0.050 \\
(0.123) \\
{[0.406]}\end{array}$ & $\begin{array}{r}0.107 \\
(0.053) \\
{[2.01]}\end{array}$ \\
\hline
\end{tabular}

Keterangan: $\quad$ Angka di dalam ( ) adalah standard error

Angka di dalam [ ] adalah $t$-statistics

Sel yang diarsir menunjukkan siknifikan secara statitistik $(t$-statistics $>2)$ 
Tabel 4. Lanjutan

\begin{tabular}{|c|c|c|c|c|c|c|c|c|c|c|c|}
\hline Blok & $\begin{array}{l}\text { Sumber Disequ- } \\
\text { ilibrium Error }\end{array}$ & $\begin{array}{l}\text { Permintaa } \\
\text { n Pertani- } \\
\text { an } \\
\text { D(LCA) }\end{array}$ & $\begin{array}{c}\text { Permintaan non } \\
\text { Pertanian } \\
\text { D(LCN })\end{array}$ & $\begin{array}{c}\text { Permintaan } \\
\text { Pertanian } \\
\text { Impor } \\
\text { D(LC_BINA) }\end{array}$ & $\begin{array}{l}\text { Permintaan non } \\
\text { Pertanian Impor } \\
\text { D(LCBIN_N1) }\end{array}$ & \begin{tabular}{|c} 
Harga \\
Pertani-an \\
DomestikD(L \\
PA)
\end{tabular} & $\begin{array}{c}\text { Harga non } \\
\text { Pertanian } \\
\text { Domestik } \\
\text { D(LPN) }\end{array}$ & $\begin{array}{l}\text { Harga Impor } \\
\text { Pertanian } \\
\text { D(LPBINA) }\end{array}$ & $\begin{array}{l}\text { Harga Impor } \\
\text { non Pertanian } \\
\text { D(LPBINN1) }\end{array}$ & $\begin{array}{c}\text { Real } \\
\text { Effective } \\
\text { Exchange } \\
\text { rate } \\
\text { D(LREER) }\end{array}$ & $\begin{array}{c}\text { Penge- } \\
\text { luaran } \\
\text { Total } \\
\mathrm{D}(\mathrm{LX})\end{array}$ \\
\hline \multirow{2}{*}{$\begin{array}{c}\text { BLOK } \\
\text { PRO- } \\
\text { DUK- } \\
\text { SI }\end{array}$} & $\begin{array}{c}\text { Output } \\
(\text { E_YN(-1)) }\end{array}$ & $\begin{array}{l}-0.016 \\
(0.027) \\
{[-0.58]}\end{array}$ & $\begin{array}{r}-0.026083 \\
(0.03746) \\
{[-0.69625]}\end{array}$ & $\begin{array}{r}-0.433177 \\
(0.15735) \\
{[-2.75288]}\end{array}$ & $\begin{array}{r}0.211360 \\
(0.08374) \\
{[2.52395]}\end{array}$ & $\begin{array}{r}-0.009457 \\
(0.02111) \\
{[-0.44806]}\end{array}$ & $\begin{array}{r}0.011455 \\
(0.01047) \\
{[1.09404]}\end{array}$ & $\begin{array}{c}0.023547 \\
(0.03864) \\
{[0.60932]}\end{array}$ & $\begin{array}{c}0.024523 \\
(0.03737) \\
{[0.65626]}\end{array}$ & $\begin{array}{c}0.067 \\
(0.065) \\
{[1.025]}\end{array}$ & $\begin{array}{l}-0.023 \\
(0.028) \\
{[-0.81]}\end{array}$ \\
\hline & $\begin{array}{l}\text { Permintaan Modal } \\
(\text { E_KN(-1)) }\end{array}$ & $\begin{array}{c}0.007 \\
(0.012) \\
{[0.59]}\end{array}$ & $\begin{array}{r}0.005781 \\
(0.01761) \\
{[0.32821]}\end{array}$ & $\begin{array}{r}-0.113890 \\
(0.07398) \\
{[-1.53945]}\end{array}$ & $\begin{array}{r}-0.008086 \\
(0.03937) \\
{[-0.20538]}\end{array}$ & $\begin{array}{r}0.027225 \\
(0.00992) \\
{[2.74369]}\end{array}$ & $\begin{array}{r}0.006809 \\
(0.00492) \\
{[1.38310]}\end{array}$ & $\begin{array}{r}0.024257 \\
(0.01817) \\
{[1.33508]}\end{array}$ & $\begin{array}{r}0.010947 \\
(0.01757) \\
{[0.62312]}\end{array}$ & $\begin{array}{r}-0.050 \\
(0.03) \\
{[-1.64]}\end{array}$ & $\begin{array}{l}-0.005 \\
(0.013) \\
{[-0.385]}\end{array}$ \\
\hline $\begin{array}{l}\text { NON } \\
\text { PER- } \\
\text { TANI- } \\
\text { AN }\end{array}$ & $\begin{array}{c}\text { Permintaan Tanga } \\
\text { Kerja } \\
\text { E_LN(-1) }\end{array}$ & $\begin{array}{c}0.014 \\
(0.137) \\
{[0.103]}\end{array}$ & $\begin{array}{r}-0.006482 \\
(0.18763) \\
{[-0.03454]}\end{array}$ & $\begin{array}{c}2.791195 \\
(0.78812) \\
{[3.54157]}\end{array}$ & $\begin{array}{r}-0.143506 \\
(0.41943) \\
{[-0.34214]}\end{array}$ & $\begin{array}{r}-0.128347 \\
(0.10571) \\
{[-1.21417]}\end{array}$ & $\begin{array}{r}-0.058999 \\
(0.05244) \\
{[-1.12504]}\end{array}$ & $\begin{array}{r}-0.225546 \\
(0.19356) \\
{[-1.16528]}\end{array}$ & $\begin{array}{c}-0.043358 \\
(0.18716) \\
{[-0.23166]}\end{array}$ & $\begin{array}{l}1.113 \\
(0.32) \\
{[3.37]}\end{array}$ & $\begin{array}{l}-0.007 \\
(0.142) \\
{[-0.055]}\end{array}$ \\
\hline $\begin{array}{c}\text { BLOK } \\
\\
\text { PRO- } \\
\text { DUK- } \\
\text { SI }\end{array}$ & $\begin{array}{l}\text { Permintaan Modal } \\
(\text { E_KA(-1)) }\end{array}$ & $\begin{array}{l}-0.030 \\
(0.026) \\
{[-1.171]}\end{array}$ & $\begin{array}{r}-0.041208 \\
(0.03604) \\
{[-1.14328]}\end{array}$ & $\begin{array}{r}-0.093164 \\
(0.15140) \\
{[-0.61536]}\end{array}$ & $\begin{array}{c}0.021523 \\
(0.08057) \\
{[0.26712]}\end{array}$ & $\begin{array}{r}-0.038153 \\
(0.02031) \\
{[-1.87888]}\end{array}$ & $\begin{array}{r}-0.003096 \\
(0.01007) \\
{[-0.30732]}\end{array}$ & $\begin{array}{r}-0.030559 \\
(0.03718) \\
{[-0.82187]}\end{array}$ & $\begin{array}{c}-0.006267 \\
(0.03595) \\
{[-0.17430]}\end{array}$ & $\begin{array}{c}-0.018 \\
(0.063) \\
{[-0.293]}\end{array}$ & $\begin{array}{c}0.007 \\
(0.027) \\
{[0.291]}\end{array}$ \\
\hline \multirow{2}{*}{$\begin{array}{l}\text { PER- } \\
\text { TANI- } \\
\text { AN }\end{array}$} & $\begin{array}{l}\text { Permintaan } \\
\text { Tenaga Kerja } \\
(\text { E_LA(-1)) }\end{array}$ & $\begin{array}{c}0.016 \\
(0.102) \\
{[0.163]}\end{array}$ & $\begin{array}{r}-0.039749 \\
(0.14035) \\
{[-0.28321]}\end{array}$ & $\begin{array}{r}-0.124312 \\
(0.58952) \\
{[-0.21087]}\end{array}$ & $\begin{array}{r}0.774106 \\
(0.31374) \\
{[2.46737]}\end{array}$ & $\begin{array}{r}0.061307 \\
(0.07907) \\
{[0.77534]}\end{array}$ & $\begin{array}{r}-0.062735 \\
(0.03923) \\
{[-1.59928]}\end{array}$ & $\begin{array}{c}-0.085747 \\
(0.14478) \\
{[-0.59225]}\end{array}$ & $\begin{array}{r}-0.048990 \\
(0.14000) \\
{[-0.34993]}\end{array}$ & $\begin{array}{c}-0.252 \\
(0.24) \\
{[-1.024]}\end{array}$ & $\begin{array}{l}-0.061 \\
(0.106) \\
{[-0.579]}\end{array}$ \\
\hline & $\begin{array}{c}\text { PENAWARAN } \\
\text { OUTPUT } \\
\text { (E_YA(-1)) }\end{array}$ & $\begin{array}{c}0.019 \\
(0.032) \\
{[0.603]}\end{array}$ & $\begin{array}{r}0.002162 \\
(0.04489) \\
{[0.04817]}\end{array}$ & $\begin{array}{r}0.721331 \\
(0.18856) \\
{[3.82545]}\end{array}$ & $\begin{array}{c}0.187044 \\
(0.10035) \\
{[1.86392]}\end{array}$ & $\begin{array}{c}-0.027141 \\
(0.02529) \\
{[-1.07316]}\end{array}$ & $\begin{array}{c}0.009631 \\
(0.01255) \\
{[0.76756]}\end{array}$ & $\begin{array}{c}0.021464 \\
(0.04631) \\
{[0.46349]}\end{array}$ & $\begin{array}{c}0.010929 \\
(0.04478) \\
{[0.24406]}\end{array}$ & $\begin{array}{l}-0.100 \\
(0.078) \\
{[-1.27]}\end{array}$ & $\begin{array}{l}-0.007 \\
(0.034) \\
{[-0.216]}\end{array}$ \\
\hline
\end{tabular}

Keterangan: $\quad$ Angka di dalam ( ) adalah standard error

Angka di dalam [ ] adalah $t$-statistics

Sel yang diarsir menunjukkan siknifikan secara statitistik $($-statistics $>2)$ 
Tabel 4. Lanjutan

\begin{tabular}{|c|c|c|c|c|c|c|c|c|c|c|c|}
\hline Blok & $\begin{array}{l}\text { Sumber Disequ- } \\
\text { ilibrium Error }\end{array}$ & $\begin{array}{l}\text { Perminta- } \\
\text { an } \\
\text { Pertanian } \\
\text { D(LCA) }\end{array}$ & $\begin{array}{l}\text { Permintaan non } \\
\text { Pertanian } \\
\text { D(LCN) }\end{array}$ & $\begin{array}{c}\text { Permintaan } \\
\text { Pertanian } \\
\text { Impor } \\
\text { D(LC_BINA) }\end{array}$ & $\begin{array}{l}\text { Permintaan non } \\
\text { Pertanian Impor } \\
\text { D(LCBIN_N1) }\end{array}$ & $\begin{array}{c}\text { Harga } \\
\text { Pertani-an } \\
\text { DomestikD( } \\
\text { LPA) }\end{array}$ & $\begin{array}{c}\text { Harga non } \\
\text { Pertanian } \\
\text { Domestik } \\
\text { D(LPN) }\end{array}$ & $\begin{array}{l}\text { Harga Impor } \\
\text { Pertanian } \\
\text { D(LPBINA) }\end{array}$ & $\begin{array}{l}\text { Harga Impor } \\
\text { non Pertanian } \\
\text { D(LPBINN1) }\end{array}$ & $\begin{array}{c}\text { Real } \\
\text { Effective } \\
\text { Exchange } \\
\text { rate } \\
\text { D(LREER) }\end{array}$ & $\begin{array}{c}\text { Penge- } \\
\text { luaran } \\
\text { Total } \\
\text { D(LX) }\end{array}$ \\
\hline \multirow{2}{*}{$\begin{array}{l}\text { BLOK } \\
\text { PER- } \\
\text { MIN- } \\
\text { TAAN } \\
\text { EKS- } \\
\text { POR }\end{array}$} & $\begin{array}{c}\text { Permintaan Ekspor } \\
\text { Pertanian } \\
\text { E_C_A(-1) }\end{array}$ & $\begin{array}{c}-0.002 \\
(0.019) \\
{[-0.109]}\end{array}$ & $\begin{array}{c}0.013635 \\
(0.02651) \\
{[0.51427]}\end{array}$ & $\begin{array}{r}0.285658 \\
(0.11136) \\
{[2.56507]}\end{array}$ & $\begin{array}{c}0.038311 \\
(0.05927) \\
{[0.64641]}\end{array}$ & $\begin{array}{r}-0.002050 \\
(0.01494) \\
{[-0.13727]}\end{array}$ & $\begin{array}{r}-0.000371 \\
(0.00741) \\
{[-0.05005]}\end{array}$ & $\begin{array}{c}0.015557 \\
(0.02735) \\
{[0.56881]}\end{array}$ & $\begin{array}{c}0.017780 \\
(0.02645) \\
{[0.67232]}\end{array}$ & $\begin{array}{r}-0.050796 \\
(0.04656) \\
{[-1.09102]}\end{array}$ & $\begin{array}{r}-0.011 \\
(0.02) \\
{[-0.55]}\end{array}$ \\
\hline & \begin{tabular}{|c|} 
Permintaan Ekspor \\
non Pertanian \\
E_C_N(-1)
\end{tabular} & $\begin{array}{c}0.0002 \\
(0.02) \\
{[0.012]}\end{array}$ & $\begin{array}{r}-0.012218 \\
(0.02828) \\
{[-0.43208]}\end{array}$ & $\begin{array}{r}-0.251533 \\
(0.11877) \\
{[-2.11775]}\end{array}$ & $\begin{array}{r}-0.061346 \\
(0.06321) \\
{[-0.97051]}\end{array}$ & $\begin{array}{r}0.002717 \\
(0.01593) \\
{[0.17057]}\end{array}$ & $\begin{array}{r}0.002748 \\
(0.00790) \\
{[0.34770]}\end{array}$ & $\begin{array}{r}-0.014641 \\
(0.02917) \\
{[-0.50192]}\end{array}$ & $\begin{array}{r}-0.017418 \\
(0.02821) \\
{[-0.61754]}\end{array}$ & $\begin{array}{r}0.040591 \\
(0.04966) \\
{[0.81746]}\end{array}$ & $\begin{array}{l}0.006 \\
(0.02) \\
{[0.30]}\end{array}$ \\
\hline \multirow{3}{*}{$\begin{array}{c}\text { PER- } \\
\text { MIN- } \\
\text { TAAN } \\
\text { ASET } \\
\text { FI- } \\
\text { NAN- } \\
\text { SIAL }\end{array}$} & $\begin{array}{c}\text { Permintaan M2 } \\
\text { E_M2(-1) }\end{array}$ & $\begin{array}{c}0.088 \\
(0.144) \\
{[0.612]}\end{array}$ & $\begin{array}{r}0.086522 \\
(0.19704) \\
{[0.43912]}\end{array}$ & $\begin{array}{c}0.292074 \\
(0.82762) \\
{[0.35291]}\end{array}$ & $\begin{array}{r}-0.707745 \\
(0.44045) \\
{[-1.60687]}\end{array}$ & $\begin{array}{r}-0.394832 \\
(0.11101) \\
{[-3.55687]}\end{array}$ & $\begin{array}{r}-0.246527 \\
(0.05507) \\
{[-4.47658]}\end{array}$ & $\begin{array}{r}-0.717696 \\
(0.20325) \\
{[-3.53102]}\end{array}$ & $\begin{array}{c}-0.316888 \\
(0.19654) \\
{[-1.61233]}\end{array}$ & $\begin{array}{l}2.031866 \\
(0.34600) \\
{[5.87241]}\end{array}$ & $\begin{array}{c}0.122 \\
(0.149) \\
{[0.81]}\end{array}$ \\
\hline & $\begin{array}{c}\text { Permintaan Bond } \\
\text { Domestik } \\
\text { E_B(-1) }\end{array}$ & $\begin{array}{c}0.010 \\
(0.013) \\
{[0.76]}\end{array}$ & $\begin{array}{r}0.008612 \\
(0.01795) \\
{[0.47973]}\end{array}$ & $\begin{array}{r}-0.075563 \\
(0.07541) \\
{[-1.00209]}\end{array}$ & $\begin{array}{r}0.002154 \\
(0.04013) \\
{[0.05368]}\end{array}$ & $\begin{array}{r}-0.026499 \\
(0.01011) \\
{[-2.62003]}\end{array}$ & $\begin{array}{r}-0.006824 \\
(0.00502) \\
{[-1.36005]}\end{array}$ & $\begin{array}{r}-0.031930 \\
(0.01852) \\
{[-1.72420]}\end{array}$ & $\begin{array}{r}-0.011215 \\
(0.01791) \\
{[-0.62627]}\end{array}$ & $\begin{array}{r}0.135380 \\
(0.03152) \\
{[4.29441]}\end{array}$ & $\begin{array}{c}0.006 \\
(0.013) \\
{[0.47]}\end{array}$ \\
\hline & $\begin{array}{l}\text { Permintaan Bond } \\
\text { Luar negeri } \\
\text { E_BBIN(-1) }\end{array}$ & $\begin{array}{l}-0.014 \\
(0.005) \\
{[-2.60]}\end{array}$ & $\begin{array}{r}-0.014494 \\
(0.00736) \\
{[-1.96967]}\end{array}$ & $\begin{array}{r}0.081538 \\
(0.03091) \\
{[2.63801]}\end{array}$ & $\begin{array}{r}0.075904 \\
(0.01645) \\
{[4.61446]}\end{array}$ & $\begin{array}{r}-0.007017 \\
(0.00415) \\
{[-1.69259]}\end{array}$ & $\begin{array}{c}0.000846 \\
(0.00206) \\
{[0.41110]}\end{array}$ & $\begin{array}{c}0.023040 \\
(0.00759) \\
{[3.03520]}\end{array}$ & $\begin{array}{l}0.017765 \\
(0.00734) \\
{[2.42034]}\end{array}$ & $\begin{array}{r}-0.041910 \\
(0.01292) \\
{[-3.24334]}\end{array}$ & $\begin{array}{l}-0.004 \\
(0.005) \\
{[-0.86]}\end{array}$ \\
\hline
\end{tabular}

Keterangan: $\quad$ Angka di dalam ( ) adalah standard error

Angka di dalam [ ] adalah $t$-statistics

Sel yang diarsir menunjukkan siknifikan secara statitistik $(t$-statistics $>2)$ 
Tabel 5. Koefisien Estimasi dari masing-masing Disequilibrium Error masing-masing Persamaan pada Setiap Blok terhadap Blok Permintaan Aset Finansial

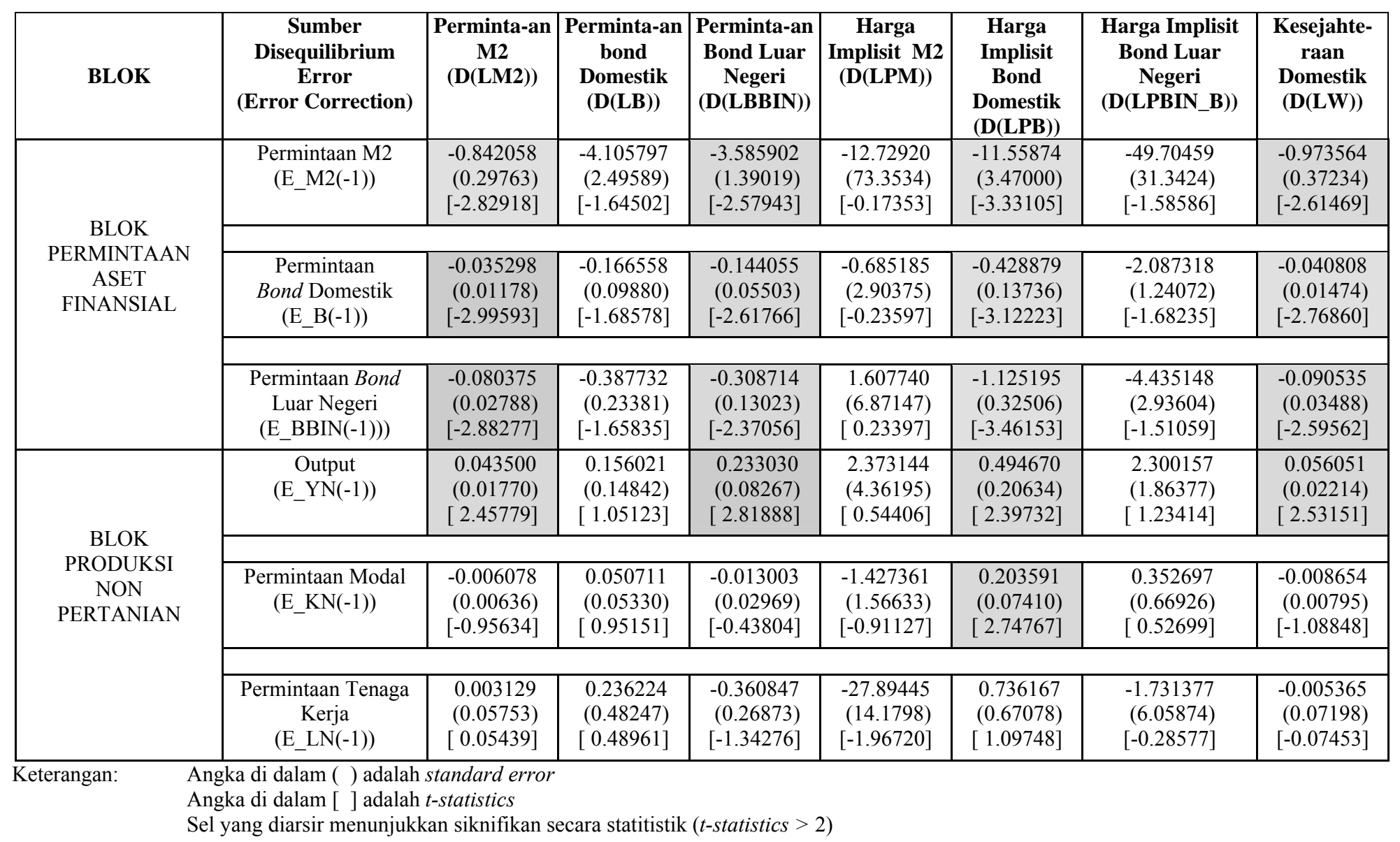


Tabel 5. Lanjutan

\begin{tabular}{|c|c|c|c|c|c|c|c|c|}
\hline BLOK & $\begin{array}{c}\text { Sumber } \\
\text { Disequilibrium } \\
\text { Error } \\
\text { (Error Correction) }\end{array}$ & $\begin{array}{c}\text { Perminta-an } \\
\text { M2 } \\
\text { (D(LM2)) }\end{array}$ & $\begin{array}{c}\text { Perminta-an } \\
\text { bond } \\
\text { Domestik } \\
\text { (D(LB)) }\end{array}$ & \begin{tabular}{|c|} 
Perminta-an \\
Bond Luar \\
Negeri \\
$(\mathrm{D}(\mathrm{LBBIN}))$
\end{tabular} & $\begin{array}{c}\text { Harga } \\
\text { Implisit M2 } \\
\text { (D(LPM)) }\end{array}$ & $\begin{array}{c}\text { Harga } \\
\text { Implisit } \\
\text { Bond } \\
\text { Domestik } \\
\text { (D(LPB)) }\end{array}$ & $\begin{array}{l}\text { Harga Implisit } \\
\text { Bond Luar } \\
\text { Negeri } \\
\text { (D(LPBIN_B)) }\end{array}$ & $\begin{array}{c}\text { Kesejahte- } \\
\text { raan } \\
\text { Domestik } \\
(\mathrm{D}(\mathrm{LW}))\end{array}$ \\
\hline \multirow{3}{*}{$\begin{array}{c}\text { BLOK } \\
\text { PRODUKSI } \\
\text { PERTANIAN }\end{array}$} & $\begin{array}{l}\text { Permintaan } \\
\text { Modal } \\
(\text { E_KA(-1)) }\end{array}$ & $\begin{array}{r}-0.010759 \\
(0.01060) \\
{[-1.01475]}\end{array}$ & $\begin{array}{r}-0.208771 \\
(0.08891) \\
{[-2.34816]}\end{array}$ & $\begin{array}{l}0.042358 \\
(0.04952) \\
{[0.85535]}\end{array}$ & $\begin{array}{r}2.819372 \\
(2.61299) \\
{[1.07898]}\end{array}$ & $\begin{array}{r}-0.202219 \\
(0.12361) \\
{[-1.63597]}\end{array}$ & $\begin{array}{r}-0.027123 \\
(1.11648) \\
{[-0.02429]}\end{array}$ & $\begin{array}{r}-0.008717 \\
(0.01326) \\
{[-0.65720]}\end{array}$ \\
\hline & $\begin{array}{c}\text { Permintaan Tenaga } \\
\text { Kerja } \\
\text { (E_LA }(-1))\end{array}$ & $\begin{array}{r}-0.008443 \\
(0.03076) \\
{[-0.27445]}\end{array}$ & $\begin{array}{r}-0.101090 \\
(0.25796) \\
{[-0.39188]}\end{array}$ & $\begin{array}{r}-0.317774 \\
(0.14368) \\
{[-2.21166]}\end{array}$ & $\begin{array}{r}-21.36630 \\
(7.58132) \\
{[-2.81828]}\end{array}$ & $\begin{array}{l}0.389336 \\
(0.35864) \\
{[1.08560]}\end{array}$ & $\begin{array}{l}6.058580 \\
(3.23935) \\
{[1.87031]}\end{array}$ & $\begin{array}{r}-0.034031 \\
(0.03848) \\
{[-0.88431]}\end{array}$ \\
\hline & $\begin{array}{c}\text { Output } \\
(\text { E_YA(-1)) }\end{array}$ & $\begin{array}{r}0.001107 \\
(0.01316) \\
{[0.08410]}\end{array}$ & $\begin{array}{r}0.262797 \\
(0.11039) \\
{[2.38073]}\end{array}$ & $\begin{array}{r}-0.094698 \\
(0.06148) \\
{[-1.54021]}\end{array}$ & $\begin{array}{r}-7.711935 \\
(3.24419) \\
{[-2.37715]}\end{array}$ & $\begin{array}{l}0.401776 \\
(0.15347) \\
{[2.61799]}\end{array}$ & $\begin{array}{l}0.100454 \\
(1.38618) \\
{[0.07247]}\end{array}$ & $\begin{array}{r}-0.001378 \\
(0.01647) \\
{[-0.08371]}\end{array}$ \\
\hline \multirow{2}{*}{$\begin{array}{c}\text { BLOK } \\
\text { PERMINTAAN } \\
\text { EKSPOR }\end{array}$} & $\begin{array}{c}\text { Pemintaan Ekspor } \\
\text { Komoditas Pertanian } \\
(\text { E_C_A }(-1))\end{array}$ & $\begin{array}{r}0.009879 \\
(0.00742) \\
{[1.33152]}\end{array}$ & $\begin{array}{l}0.114546 \\
(0.06222) \\
{[1.84101]}\end{array}$ & $\begin{array}{l}0.002982 \\
(0.03466) \\
{[0.08605]}\end{array}$ & $\begin{array}{r}-2.638159 \\
(1.82860) \\
{[-1.44272]}\end{array}$ & $\begin{array}{r}0.291231 \\
(0.08650) \\
{[3.36674]}\end{array}$ & $\begin{array}{l}1.305329 \\
(0.78132) \\
{[1.67067]}\end{array}$ & $\begin{array}{l}0.011412 \\
(0.00928) \\
{[1.22943]}\end{array}$ \\
\hline & $\begin{array}{c}\text { Permintaan Ekspor } \\
\text { Komoditas non } \\
\text { Pertanian } \\
(\text { E C N }(-1))\end{array}$ & $\begin{array}{l}-0.009617 \\
(0.00788) \\
{[-1.21964]}\end{array}$ & $\begin{array}{r}-0.111882 \\
(0.06612) \\
{[-1.69206]}\end{array}$ & $\begin{array}{r}-0.020298 \\
(0.03683) \\
{[-0.55113]}\end{array}$ & $\begin{array}{l}2.469925 \\
(1.94329) \\
{[1.27100]}\end{array}$ & $\begin{array}{r}-0.295729 \\
(0.09193) \\
{[-3.21696]}\end{array}$ & $\begin{array}{r}-1.567818 \\
(0.83033) \\
{[-1.88819]}\end{array}$ & $\begin{array}{r}-0.012784 \\
(0.00986) \\
{[-1.29603]}\end{array}$ \\
\hline
\end{tabular}

Keterangan: $\quad$ Angka di dalam ( ) adalah standard error

Angka di dalam [ ] adalah $t$-statistics

Sel yang diarsir menunjukkan siknifikan secara statitistik $($-statistics $>2)$ 
Tabel 5. Lanjutan

\begin{tabular}{|c|c|c|c|c|c|c|c|c|}
\hline BLOK & $\begin{array}{c}\text { Sumber } \\
\text { Disequilibrium } \\
\text { Error } \\
\text { (Error Correction) }\end{array}$ & $\begin{array}{c}\text { Perminta-an } \\
\text { M2 } \\
\text { (D(LM2)) }\end{array}$ & $\begin{array}{c}\text { Perminta-an } \\
\text { bond } \\
\text { Domestik } \\
\text { (D(LB)) }\end{array}$ & \begin{tabular}{|c|} 
Perminta-an \\
Bond Luar \\
Negeri \\
(D(LBBIN))
\end{tabular} & $\begin{array}{c}\text { Harga } \\
\text { Implisit M2 } \\
(\mathrm{D}(\mathrm{LPM}))\end{array}$ & $\begin{array}{l}\text { Harga } \\
\text { Implisit } \\
\text { Bond } \\
\text { Domestik } \\
(\mathrm{D}(\text { LPB }))\end{array}$ & $\begin{array}{l}\text { Harga Implisit } \\
\text { Bond Luar } \\
\text { Negeri } \\
\text { (D(LPBIN_B)) }\end{array}$ & $\begin{array}{c}\text { Kesejahte- } \\
\text { raan } \\
\text { Domestik } \\
(\mathrm{D}(\mathrm{LW}))\end{array}$ \\
\hline \multirow{4}{*}{$\begin{array}{c}\text { BLOK } \\
\text { PERMINTAAN } \\
\text { KOMODITAS }\end{array}$} & $\begin{array}{c}\text { Permintaan } \\
\text { Komoditas } \\
\text { Pertanian Impor } \\
(\text { E_C_BINA(-1)) }\end{array}$ & $\begin{array}{c}0.002661 \\
(0.00869) \\
{[0.30626]}\end{array}$ & $\begin{array}{r}0.170184 \\
(0.07286) \\
{[2.33583]}\end{array}$ & $\begin{array}{r}-0.016040 \\
(0.04058) \\
{[-0.39526]}\end{array}$ & $\begin{array}{r}2.880250 \\
(2.14127) \\
{[1.34511]}\end{array}$ & $\begin{array}{r}0.003717 \\
(0.10129) \\
{[0.03670]}\end{array}$ & $\begin{array}{r}-0.355249 \\
(0.91492) \\
{[-0.38828]}\end{array}$ & $\begin{array}{r}0.004755 \\
(0.01087) \\
{[0.43745]}\end{array}$ \\
\hline & $\begin{array}{c}\text { Permintaan } \\
\text { Komoditas Pertanian } \\
\text { Domestik } \\
(\text { E_CA }(-1)) \\
\end{array}$ & $\begin{array}{c}0.152108 \\
(0.09290) \\
{[1.63727]}\end{array}$ & $\begin{array}{c}1.148055 \\
(0.77907) \\
{[1.47362]}\end{array}$ & $\begin{array}{r}-0.489156 \\
(0.43394) \\
{[-1.12725]}\end{array}$ & $\begin{array}{c}4.377269 \\
(22.8966) \\
{[0.19118]}\end{array}$ & $\begin{array}{r}1.010070 \\
(1.08313) \\
{[0.93255]}\end{array}$ & $\begin{array}{r}-7.094349 \\
(9.78327) \\
{[-0.72515]}\end{array}$ & $\begin{array}{r}0.135982 \\
(0.11622) \\
{[1.17000]}\end{array}$ \\
\hline & $\begin{array}{c}\text { Permintaan } \\
\text { Komoditas non } \\
\text { Pertanian Domestik } \\
(\text { E_CN }(-1))\end{array}$ & $\begin{array}{r}0.030910 \\
(0.05414) \\
{[0.57095]}\end{array}$ & $\begin{array}{r}0.257024 \\
(0.45400) \\
{[0.56614]}\end{array}$ & $\begin{array}{r}0.224577 \\
(0.25287) \\
{[0.88811]}\end{array}$ & $\begin{array}{c}6.860068 \\
(13.3428) \\
{[0.51414]}\end{array}$ & $\begin{array}{c}-0.319693 \\
(0.63118) \\
{[-0.50650]}\end{array}$ & $\begin{array}{r}-3.538770 \\
(5.70110) \\
{[-0.62072]}\end{array}$ & $\begin{array}{r}0.059521 \\
(0.06773) \\
{[0.87881]}\end{array}$ \\
\hline & $\begin{array}{c}\text { Permintaan } \\
\text { Komoditas non } \\
\text { Pertanian Impor } \\
\text { (E CBIN N1(-1)) }\end{array}$ & $\begin{array}{r}0.006546 \\
(0.01484) \\
{[0.44114]}\end{array}$ & $\begin{array}{r}-0.076272 \\
(0.12444) \\
{[-0.61294]}\end{array}$ & $\begin{array}{r}0.056862 \\
(0.06931) \\
{[0.82040]}\end{array}$ & $\begin{array}{c}2.695065 \\
(3.65713) \\
{[0.73694]}\end{array}$ & $\begin{array}{r}-0.387030 \\
(0.17300) \\
{[-2.23715]}\end{array}$ & $\begin{array}{r}-0.968806 \\
(1.56262) \\
{[-0.61999]}\end{array}$ & $\begin{array}{r}0.013963 \\
(0.01856) \\
{[0.75214]}\end{array}$ \\
\hline
\end{tabular}

Keterangan: $\quad$ Angka di dalam ( ) adalah standard error

Angka di dalam [ ] adalah $t$-statistics

Sel yang diarsir menunjukkan siknifikan secara statitistik ( $t$-statistics $>2)$ 
Tabel 6. Koefisien Estimasi dari masing-masing Disequilibrium Error masing-masing Persamaan pada Setiap Blok terhadap Blok Produksi Pertanian

\begin{tabular}{|c|c|c|c|c|c|c|c|c|}
\hline BLOK & \begin{tabular}{|c|} 
Sumber \\
Disequilibriu \\
m Error \\
(Error \\
Correction) \\
\end{tabular} & $\begin{array}{l}\text { Output Pertanian } \\
\text { (D(LYA)) }\end{array}$ & $\begin{array}{l}\text { Permintaan } \\
\text { Modal } \\
\text { Pertanian } \\
\text { (D(LKA)) }\end{array}$ & $\begin{array}{l}\text { Permintaan } \\
\text { Tenaga Kerja } \\
\text { Pertanian } \\
\text { (D(LLA)) }\end{array}$ & $\begin{array}{c}\text { Suku Bunga } \\
\text { D(r) }\end{array}$ & $\begin{array}{c}\text { Upah Riil Sektor } \\
\text { Pertanian } \\
\text { (D(LWA/LPA)) }\end{array}$ & $\begin{array}{c}\text { Harga Material Riil } \\
\text { Pertanian } \\
\text { (D(LPMA/LPA)) }\end{array}$ & $\begin{array}{c}\text { Harga } \\
\text { Pertanian } \\
\text { (D(LPA)) }\end{array}$ \\
\hline \multirow{3}{*}{$\begin{array}{c}\text { BLOK } \\
\text { PRODUK-SI } \\
\text { PERTANI- } \\
\text { AN }\end{array}$} & $\begin{array}{c}\text { Output } \\
(\text { E_YA(-1)) }\end{array}$ & $\begin{array}{r}-0.477784 \\
(0.07169) \\
{[-6.66453]}\end{array}$ & $\begin{array}{l}0.068913 \\
(0.05419) \\
{[1.27162]}\end{array}$ & $\begin{array}{l}0.014768 \\
(0.01252) \\
{[1.17911]}\end{array}$ & $\begin{array}{r}-1.606214 \\
(3.69800) \\
{[-0.43435]}\end{array}$ & $\begin{array}{l}0.014973 \\
(0.00556) \\
{[2.69243]}\end{array}$ & $\begin{array}{l}0.004813 \\
(0.00398) \\
{[1.20984]}\end{array}$ & $\begin{array}{r}-0.049523 \\
(0.02119) \\
{[-2.33692]}\end{array}$ \\
\hline & $\begin{array}{c}\begin{array}{c}\text { Perminta-an } \\
\text { Modal } \\
\left(\mathrm{E} \_\mathrm{KA}(-1)\right)\end{array} \\
\end{array}$ & $\begin{array}{r}0.406212 \\
(0.10361) \\
{[3.92072]} \\
\end{array}$ & $\begin{array}{r}-0.125919 \\
(0.07832) \\
{[-1.60777]}\end{array}$ & $\begin{array}{r}-0.014923 \\
(0.01810) \\
{[-0.82443]}\end{array}$ & $\begin{array}{r}0.582527 \\
(5.34432) \\
{[0.10900]}\end{array}$ & $\begin{array}{r}-0.020852 \\
(0.00804) \\
{[-2.59460]}\end{array}$ & $\begin{array}{l}0.003616 \\
(0.00575) \\
{[0.62896]}\end{array}$ & $\begin{array}{l}0.074122 \\
(0.03063) \\
{[2.42023]}\end{array}$ \\
\hline & \begin{tabular}{l|} 
Perminta-an \\
Tenaga Kerja \\
$($ E_LA(-1)) \\
\end{tabular} & $\begin{array}{r}0.442674 \\
(0.07601) \\
{[5.82355]}\end{array}$ & $\begin{array}{r}-0.071340 \\
(0.05746) \\
{[-1.24152]}\end{array}$ & $\begin{array}{c}-0.017295 \\
(0.01328) \\
{[-1.30233]}\end{array}$ & $\begin{array}{r}3.148447 \\
(3.92104) \\
{[0.80296]}\end{array}$ & $\begin{array}{r}-0.020259 \\
(0.00590) \\
{[-3.43585]}\end{array}$ & $\begin{array}{r}-0.012208 \\
(0.00422) \\
{[-2.89399]}\end{array}$ & $\begin{array}{l}0.072151 \\
(0.02247) \\
{[3.21102]}\end{array}$ \\
\hline \multirow{3}{*}{$\begin{array}{l}\text { BLOK } \\
\text { PRODUK-SI } \\
\text { NON } \\
\text { PERTANI- } \\
\text { AN }\end{array}$} & $\begin{array}{c}\text { Output } \\
(\text { E_YN(-1)) }\end{array}$ & $\begin{array}{r}-0.120763 \\
(0.07209) \\
{[-1.67508]}\end{array}$ & $\begin{array}{l}0.122133 \\
(0.05450) \\
{[2.24104]}\end{array}$ & $\begin{array}{r}-0.002045 \\
(0.01260) \\
{[-0.16239]}\end{array}$ & $\begin{array}{l}9.627921 \\
(3.71883) \\
{[2.58897]}\end{array}$ & $\begin{array}{r}-0.002523 \\
(0.00559) \\
{[-0.45113]}\end{array}$ & $\begin{array}{c}0.000613 \\
(0.00400) \\
{[0.15315]}\end{array}$ & $\begin{array}{l}0.006349 \\
(0.02131) \\
{[0.29790]}\end{array}$ \\
\hline & \begin{tabular}{|l|} 
Perminta-an \\
Modal \\
$\left(\mathrm{E} \_\mathrm{KN}(-1)\right)$
\end{tabular} & $\begin{array}{r}-0.148764 \\
(0.03477) \\
{[-4.27900]}\end{array}$ & $\begin{array}{c}-0.023578 \\
(0.02628) \\
{[-0.89715]}\end{array}$ & $\begin{array}{l}0.002335 \\
(0.00607) \\
{[0.38437]}\end{array}$ & $\begin{array}{r}-1.754734 \\
(1.79333) \\
{[-0.97848]}\end{array}$ & $\begin{array}{r}-0.000330 \\
(0.00270) \\
{[-0.12235]}\end{array}$ & $\begin{array}{r}-0.001887 \\
(0.00193) \\
{[-0.97797]}\end{array}$ & $\begin{array}{l}0.007330 \\
(0.01028) \\
{[0.71325]}\end{array}$ \\
\hline & \begin{tabular}{|c|} 
Perminta-an \\
Tenaga Kerja \\
$($ E_LN(-1))
\end{tabular} & $\begin{array}{c}-0.265695 \\
(0.33447) \\
{[-0.79437]}\end{array}$ & $\begin{array}{r}-0.090181 \\
(0.25284) \\
{[-0.35667]}\end{array}$ & $\begin{array}{l}0.033795 \\
(0.05843) \\
{[0.57834]}\end{array}$ & $\begin{array}{l}33.39562 \\
(17.2530) \\
{[1.93564]}\end{array}$ & $\begin{array}{l}0.045944 \\
(0.02595) \\
{[1.77081]}\end{array}$ & $\begin{array}{r}-0.032196 \\
(0.01856) \\
{[-1.73461]}\end{array}$ & $\begin{array}{r}-0.159553 \\
(0.09887) \\
{[-1.61377]}\end{array}$ \\
\hline
\end{tabular}

Keterangan:

Angka di dalam ( ) adalah standard error

Angka di dalam [ ] adalah t-statistics

Sel yang diarsir menunjukkan siknifikan secara statitistik $($-statistics $>2)$ 
Tabel 6. Lanjutan

\begin{tabular}{|c|c|c|c|c|c|c|c|c|}
\hline BLOK & $\begin{array}{c}\text { Sumber } \\
\text { Disequilibrium } \\
\text { Error (Error } \\
\text { Correction) } \\
\end{array}$ & $\begin{array}{l}\text { Output Pertanian } \\
\text { (D(LYA)) }\end{array}$ & $\begin{array}{l}\text { Permintaan } \\
\text { Modal } \\
\text { Pertanian } \\
\text { (D(LKA)) } \\
\end{array}$ & $\begin{array}{c}\text { Permintaan } \\
\text { Tenaga Kerja } \\
\text { Pertanian } \\
\text { (D(LLA)) } \\
\end{array}$ & $\begin{array}{c}\text { Suku Bunga } \\
\text { D(r) }\end{array}$ & $\begin{array}{c}\text { Upah Riil Sektor } \\
\text { Pertanian } \\
\text { (D(LWA/LPA)) }\end{array}$ & $\begin{array}{c}\text { Harga Material Riil } \\
\text { Pertanian } \\
\text { (D(LPMA/LPA)) }\end{array}$ & $\begin{array}{c}\text { Harga } \\
\text { Pertanian } \\
(\text { D(LPA)) }\end{array}$ \\
\hline \multirow{2}{*}{$\begin{array}{l}\text { PERMIN- } \\
\text { TAAN } \\
\text { EKSPOR }\end{array}$} & $\begin{array}{c}\text { Permintaan } \\
\text { Ekspor } \\
\text { Komoditas } \\
\text { Pertanian } \\
\text { (E_C_A(-1)) }\end{array}$ & $\begin{array}{r}-0.015360 \\
(0.04366) \\
{[-0.35184]}\end{array}$ & $\begin{array}{c}0.027987 \\
(0.03300) \\
{[0.84806]}\end{array}$ & $\begin{array}{r}0.000135 \\
(0.00763) \\
{[0.01771]}\end{array}$ & $\begin{array}{r}0.386709 \\
(2.25192) \\
{[0.17172]}\end{array}$ & $\begin{array}{r}0.003039 \\
(0.00339) \\
{[0.89752]}\end{array}$ & $\begin{array}{r}-0.000384 \\
(0.00242) \\
{[-0.15840]}\end{array}$ & $\begin{array}{r}-0.014073 \\
(0.01290) \\
{[-1.09051]}\end{array}$ \\
\hline & $\begin{array}{c}\text { Permintaan } \\
\text { Ekspor } \\
\text { Komoditas non } \\
\text { Pertanian } \\
\text { (E_C_N(-1)) }\end{array}$ & $\begin{array}{r}0.015387 \\
(0.04662) \\
{[0.33006]}\end{array}$ & $\begin{array}{r}-0.027676 \\
(0.03524) \\
{[-0.78532]}\end{array}$ & $\begin{array}{l}0.001408 \\
(0.00814) \\
{[0.17284]}\end{array}$ & $\begin{array}{r}-1.116694 \\
(2.40481) \\
{[-0.46436]}\end{array}$ & $\begin{array}{r}-0.003112 \\
(0.00362) \\
{[-0.86043]}\end{array}$ & $\begin{array}{r}-0.000162 \\
(0.00259) \\
{[-0.06268]}\end{array}$ & $\begin{array}{r}0.014208 \\
(0.01378) \\
{[1.03098]}\end{array}$ \\
\hline \multirow{3}{*}{$\begin{array}{l}\text { BLOK } \\
\text { PERMIN- } \\
\text { TAAN } \\
\text { ASET } \\
\text { FINANSI- } \\
\text { AL }\end{array}$} & $\begin{array}{l}\text { Permintaan M2 } \\
\text { (E_M2(-1)) }\end{array}$ & $\begin{array}{r}-1.043170 \\
(0.40856) \\
{[-2.55330]}\end{array}$ & $\begin{array}{l}0.163764 \\
(0.30884) \\
{[0.53025]}\end{array}$ & $\begin{array}{l}0.109773 \\
(0.07138) \\
{[1.53794]}\end{array}$ & $\begin{array}{r}-49.10810 \\
(21.0745) \\
{[-2.33021]}\end{array}$ & $\begin{array}{r}0.036444 \\
(0.03169) \\
{[1.14994]}\end{array}$ & $\begin{array}{r}0.038779 \\
(0.02267) \\
{[1.71044]}\end{array}$ & $\begin{array}{r}-0.142240 \\
(0.12077) \\
{[-1.17779]}\end{array}$ \\
\hline & $\begin{array}{c}\text { Permintaan } \\
\text { bond Domestik } \\
\left(\mathrm{E} \_\mathrm{B}(-1)\right)\end{array}$ & $\begin{array}{r}-0.064931 \\
(0.02983) \\
{[-2.17703]}\end{array}$ & $\begin{array}{r}0.025202 \\
(0.02255) \\
{[1.11782]}\end{array}$ & $\begin{array}{r}0.003775 \\
(0.00521) \\
{[0.72453]}\end{array}$ & $\begin{array}{r}-2.431686 \\
(1.53848) \\
{[-1.58058]}\end{array}$ & $\begin{array}{r}0.000910 \\
(0.00231) \\
{[0.39312]}\end{array}$ & $\begin{array}{r}0.001849 \\
(0.00166) \\
{[1.11698]}\end{array}$ & $\begin{array}{r}-0.003700 \\
(0.00882) \\
{[-0.41964]}\end{array}$ \\
\hline & $\begin{array}{c}\text { Permintaan } \\
\text { Bond Luar } \\
\text { Negeri } \\
\text { (E_BBIN(-1)) }\end{array}$ & $\begin{array}{r}-0.073946 \\
(0.02332) \\
{[-3.17097]}\end{array}$ & $\begin{array}{r}-0.008036 \\
(0.01763) \\
{[-0.45588]}\end{array}$ & $\begin{array}{l}0.000458 \\
(0.00407) \\
{[0.11237]}\end{array}$ & $\begin{array}{r}0.017700 \\
(1.20290) \\
{[0.01471]}\end{array}$ & $\begin{array}{r}-0.000178 \\
(0.00181) \\
{[-0.09846]}\end{array}$ & $\begin{array}{r}0.001978 \\
(0.00129) \\
{[1.52847]}\end{array}$ & $\begin{array}{r}0.001873 \\
(0.00689) \\
{[0.27170]}\end{array}$ \\
\hline
\end{tabular}

Keterangan:

Angka di dalam ( ) adalah standard error

Angka di dalam [ ] adalah $t$-statistics

Sel yang diarsir menunjukkan siknifikan secara statitistik $(t$-statistics $>2)$ 
Tabel 6. Lanjutan

\begin{tabular}{|c|c|c|c|c|c|c|c|c|}
\hline BLOK & $\begin{array}{c}\text { Sumber } \\
\text { Disequilibrium } \\
\text { Error (Error } \\
\text { Correction) }\end{array}$ & $\begin{array}{c}\text { Output } \\
\text { Pertanian } \\
(\text { D(LYA)) }\end{array}$ & $\begin{array}{l}\text { Permintaan } \\
\text { Modal } \\
\text { Pertanian } \\
\text { (D(LKA)) }\end{array}$ & $\begin{array}{c}\text { Permintaan } \\
\text { Tenaga Kerja } \\
\text { Pertanian } \\
\text { (D(LLA)) }\end{array}$ & $\begin{array}{c}\text { Suku Bunga } \\
\text { D(r) }\end{array}$ & $\begin{array}{c}\text { Upah Riil Sektor } \\
\text { Pertanian } \\
\text { (D(LWA/LPA)) }\end{array}$ & $\begin{array}{c}\text { Harga Material Riil } \\
\text { Pertanian } \\
\text { (D(LPMA/LPA)) }\end{array}$ & $\begin{array}{c}\text { Harga } \\
\text { Pertanian } \\
(\text { D(LPA)) }\end{array}$ \\
\hline \multirow{4}{*}{$\begin{array}{l}\text { PERMIN- } \\
\text { TAAN } \\
\text { KOMODI- } \\
\text { TAS }\end{array}$} & $\begin{array}{l}\text { Permintaan } \\
\text { Komoditas Pertanian } \\
\text { Impor }\left(E_{-} C_{-} \text {_BINA(- }\right.\end{array}$ & $\begin{array}{r}-0.049621 \\
(0.04583) \\
{[-1.08265]}\end{array}$ & $\begin{array}{c}-0.015898 \\
(0.03465) \\
{[-0.45887]}\end{array}$ & $\begin{array}{c}0.001057 \\
(0.00801) \\
{[0.13197]}\end{array}$ & $\begin{array}{r}3.752754 \\
(2.36421) \\
{[1.58732]}\end{array}$ & $\begin{array}{r}-0.002546 \\
(0.00356) \\
{[-0.71612]}\end{array}$ & $\begin{array}{r}0.001430 \\
(0.00254) \\
{[0.56211]}\end{array}$ & $\begin{array}{l}0.008820 \\
(0.01355) \\
{[0.65104]}\end{array}$ \\
\hline & $\begin{array}{c}\text { Permintaan } \\
\text { Komoditas Pertanian } \\
\text { Domestik (E_CA(- } \\
\text { 1)) } \\
\end{array}$ & $\begin{array}{r}-0.198874 \\
(0.49064) \\
{[-0.40534]}\end{array}$ & $\begin{array}{r}0.155306 \\
(0.37089) \\
{[0.41874]}\end{array}$ & $\begin{array}{r}0.126802 \\
(0.08572) \\
{[1.47931]}\end{array}$ & $\begin{array}{r}-36.96758 \\
(25.3085) \\
{[-1.46068]}\end{array}$ & $\begin{array}{r}0.031579 \\
(0.03806) \\
{[0.82973]}\end{array}$ & $\begin{array}{r}-0.009901 \\
(0.02723) \\
{[-0.36364]}\end{array}$ & $\begin{array}{r}-0.058094 \\
(0.14503) \\
{[-0.40056]}\end{array}$ \\
\hline & $\begin{array}{c}\text { Permintaan } \\
\text { Komoditas non } \\
\text { Pertanian Domestik } \\
(\text { E_CN }(-1))\end{array}$ & $\begin{array}{r}0.115304 \\
(0.34109) \\
{[0.33805]}\end{array}$ & $\begin{array}{r}0.202955 \\
(0.25784) \\
{[0.78714]}\end{array}$ & $\begin{array}{r}-0.001535 \\
(0.05959) \\
{[-0.02577]}\end{array}$ & $\begin{array}{r}10.65940 \\
(17.5942) \\
{[0.60585]}\end{array}$ & $\begin{array}{r}-0.036063 \\
(0.02646) \\
{[-1.36302]}\end{array}$ & $\begin{array}{r}0.004344 \\
(0.01893) \\
{[0.22949]}\end{array}$ & $\begin{array}{l}0.106849 \\
(0.10082) \\
{[1.05976]}\end{array}$ \\
\hline & $\begin{array}{c}\text { Permintaan } \\
\text { Komoditas non } \\
\text { Pertanian Impor } \\
(\text { E_CBIN_N1(-1)) }\end{array}$ & $\begin{array}{r}0.112368 \\
(0.09077) \\
{[1.23791]}\end{array}$ & $\begin{array}{r}0.079955 \\
(0.06862) \\
{[1.16523]}\end{array}$ & $\begin{array}{r}-0.005217 \\
(0.01586) \\
{[-0.32896]}\end{array}$ & $\begin{array}{r}-5.343706 \\
(4.68230) \\
{[-1.14126]}\end{array}$ & $\begin{array}{r}-0.013457 \\
(0.00704) \\
{[-1.91120]}\end{array}$ & $\begin{array}{r}-0.007878 \\
(0.00504) \\
{[-1.56387]}\end{array}$ & $\begin{array}{r}0.047073 \\
(0.02683) \\
{[1.75434]}\end{array}$ \\
\hline
\end{tabular}

Keterangan:

Angka di dalam ( ) adalah standard error

Angka di dalam [ ] adalah $t$-statistics

Sel yang diarsir menunjukkan siknifikan secara statitistik ( $t$-statistics $>2)$ 
Tabel 7. Koefisien Estimasi dari masing-masing Disequilibrium Error masing-masing Persamaan pada Setiap Blok terhadap Blok Produksi non Pertanian

\begin{tabular}{|c|c|c|c|c|c|c|c|c|}
\hline BLOK & $\begin{array}{c}\text { Sumber } \\
\text { Disequilibrium } \\
\text { Error (Error } \\
\text { Coorection) } \\
\end{array}$ & $\begin{array}{l}\text { Produksi non } \\
\text { Pertanian } \\
\text { (D(LYN)) }\end{array}$ & $\begin{array}{c}\text { Permintaan } \\
\text { Modal non } \\
\text { pertanian } \\
(\mathrm{D}(\mathrm{LKN})) \\
\end{array}$ & $\begin{array}{c}\text { Permintaan } \\
\text { Tenaga Kerja } \\
\text { non Pertanian } \\
\text { D(LLN) } \\
\end{array}$ & $\begin{array}{l}\text { Suku Bunga } \\
\text { (D(r)) }\end{array}$ & $\begin{array}{c}\text { Upah rill } \\
\text { Tenaga Kerja } \\
\text { non Pertanian } \\
(\mathrm{D}(\mathrm{LWNPN}))\end{array}$ & \begin{tabular}{|c|} 
Harga Material \\
Riil non \\
Pertanian \\
D(LPMNPN) \\
\end{tabular} & $\begin{array}{c}\text { Harga } \\
\text { komoditas non } \\
\text { Pertanian } \\
(\mathrm{D}(\mathrm{LPN})) \\
\end{array}$ \\
\hline \multirow{3}{*}{$\begin{array}{c}\text { BLOK } \\
\text { PRODUKSI } \\
\text { NON } \\
\text { PERTANIAN }\end{array}$} & $\begin{array}{c}\text { Output } \\
(\text { E_YN(-1)) }\end{array}$ & $\begin{array}{r}-0.143222 \\
(0.03025) \\
{[-4.73394]}\end{array}$ & $\begin{array}{c}0.344245 \\
(0.20228) \\
{[1.70184]}\end{array}$ & $\begin{array}{r}-0.039044 \\
(0.02184) \\
{[-1.78810]}\end{array}$ & $\begin{array}{r}17.70699 \\
(5.45973) \\
{[3.24320]}\end{array}$ & $\begin{array}{r}-0.000560 \\
(0.01070) \\
{[-0.05234]}\end{array}$ & $\begin{array}{c}0.015601 \\
(0.00608) \\
{[2.56798]}\end{array}$ & $\begin{array}{r}-0.012183 \\
(0.02715) \\
{[-0.44868]}\end{array}$ \\
\hline & $\begin{array}{l}\text { Permintaan Modal } \\
(\text { E_KN(-1)) }\end{array}$ & $\begin{array}{r}-0.018151 \\
(0.01066) \\
{[-1.70291]}\end{array}$ & $\begin{array}{r}-0.007120 \\
(0.07126) \\
{[-0.09991]}\end{array}$ & $\begin{array}{r}-0.003876 \\
(0.00769) \\
{[-0.50388]}\end{array}$ & $\begin{array}{c}14.45261 \\
(1.92351) \\
{[7.51365]}\end{array}$ & $\begin{array}{r}-0.013354 \\
(0.00377) \\
{[-3.54339]}\end{array}$ & $\begin{array}{r}0.004612 \\
(0.00214) \\
{[2.15481]}\end{array}$ & $\begin{array}{c}0.031751 \\
(0.00957) \\
{[3.31904]}\end{array}$ \\
\hline & $\begin{array}{l}\text { Permintaan Tenaga } \\
\text { Kerja (E_LN(-1)) }\end{array}$ & $\begin{array}{c}0.079341 \\
(0.01875) \\
{[4.23068]}\end{array}$ & $\begin{array}{r}-0.092563 \\
(0.12539) \\
{[-0.73822]}\end{array}$ & $\begin{array}{r}0.018119 \\
(0.01354) \\
{[1.33866]}\end{array}$ & $\begin{array}{r}-25.31933 \\
(3.38432) \\
{[-7.48135]}\end{array}$ & $\begin{array}{c}0.013626 \\
(0.00663) \\
{[2.05504]}\end{array}$ & $\begin{array}{r}-0.011055 \\
(0.00377) \\
{[-2.93560]}\end{array}$ & $\begin{array}{r}-0.028493 \\
(0.01683) \\
{[-1.69282]}\end{array}$ \\
\hline \multirow{3}{*}{$\begin{array}{c}\text { BLOK } \\
\text { PRODUKSI } \\
\text { PERTANIAN }\end{array}$} & $\begin{array}{l}\text { Permintaan Modal } \\
\text { (E_KA }(-1))\end{array}$ & $\begin{array}{r}-0.012254 \\
(0.01030) \\
{[-1.18976]}\end{array}$ & $\begin{array}{r}-0.013623 \\
(0.06886) \\
{[-0.19783]}\end{array}$ & $\begin{array}{r}-0.002597 \\
(0.00743) \\
{[-0.34933]}\end{array}$ & $\begin{array}{c}-0.383719 \\
(1.85870) \\
{[-0.20644]}\end{array}$ & $\begin{array}{r}0.000705 \\
(0.00364) \\
{[0.19369]}\end{array}$ & $\begin{array}{r}0.000359 \\
(0.00207) \\
{[0.17358]}\end{array}$ & $\begin{array}{r}-1.47 \mathrm{E}-05 \\
(0.00924) \\
{[-0.00159]}\end{array}$ \\
\hline & $\begin{array}{c}\text { Permintaan Tenaga } \\
\text { kerja (E_LA(-1)) }\end{array}$ & $\begin{array}{c}-0.044251 \\
(0.04332) \\
{[-1.02152]}\end{array}$ & $\begin{array}{c}-0.057919 \\
(0.28963) \\
{[-0.19998]}\end{array}$ & $\begin{array}{r}0.076722 \\
(0.03126) \\
{[2.45397]}\end{array}$ & $\begin{array}{r}4.986464 \\
(7.81735) \\
{[0.63787]}\end{array}$ & $\begin{array}{r}0.012130 \\
(0.01532) \\
{[0.79199]}\end{array}$ & $\begin{array}{r}0.005640 \\
(0.00870) \\
{[0.64836]}\end{array}$ & $\begin{array}{c}-0.045183 \\
(0.03888) \\
{[-1.16215]}\end{array}$ \\
\hline & $\begin{array}{c}\text { Output } \\
(\text { E_YA(-1)) }\end{array}$ & $\begin{array}{l}0.018143 \\
(0.01715) \\
{[1.05766]}\end{array}$ & $\begin{array}{l}0.376285 \\
(0.11469) \\
{[3.28078]}\end{array}$ & $\begin{array}{c}-0.005041 \\
(0.01238) \\
{[-0.40715]}\end{array}$ & $\begin{array}{l}3.856567 \\
(3.09572) \\
{[1.24578]}\end{array}$ & $\begin{array}{c}-0.011228 \\
(0.00607) \\
{[-1.85115]}\end{array}$ & $\begin{array}{c}0.009924 \\
(0.00344) \\
{[2.88088]}\end{array}$ & $\begin{array}{l}0.021656 \\
(0.01540) \\
{[1.40659]}\end{array}$ \\
\hline
\end{tabular}

Angka di dalam ( ) adalah standard error

Sel yang diarsir menunjukkan siknifikan secara statitistik ( $t$-statistics $>2)$ 
Tabel 7. Lanjutan

\begin{tabular}{|c|c|c|c|c|c|c|c|c|}
\hline BLOK & $\begin{array}{c}\text { Sumber } \\
\text { Disequilibrium } \\
\text { Error (Error } \\
\text { Coorection) }\end{array}$ & $\begin{array}{l}\text { Produksi non } \\
\text { Pertanian } \\
(\mathrm{D}(\mathrm{LYN}))\end{array}$ & $\begin{array}{l}\text { Permintaan } \\
\text { Modal non } \\
\text { pertanian } \\
(\mathrm{D}(\mathrm{LKN}))\end{array}$ & $\begin{array}{c}\text { Permintaan } \\
\text { Tenaga Kerja } \\
\text { non Pertanian } \\
\text { D(LLN) }\end{array}$ & $\begin{array}{l}\text { Suku Bunga } \\
\text { (D(r)) }\end{array}$ & $\begin{array}{c}\text { Upah rill } \\
\text { Tenaga Kerja } \\
\text { non Pertanian } \\
(\mathrm{D}(\mathrm{LWNPN}))\end{array}$ & $\begin{array}{c}\text { Harga Material } \\
\text { Riil non } \\
\text { Pertanian } \\
\text { D(LPMNPN) }\end{array}$ & $\begin{array}{c}\text { Harga } \\
\text { komoditas non } \\
\text { Pertanian } \\
(\mathrm{D}(\mathrm{LPN}))\end{array}$ \\
\hline \multirow[t]{2}{*}{$\begin{array}{c}\text { BLOK } \\
\text { PERMINTA- } \\
\text { AN } \\
\text { EKSPOR }\end{array}$} & $\begin{array}{c}\text { Permintaan } \\
\text { Komoditas Ekspor } \\
\text { Pertanian (E_C_A(- } \\
\text { 1)) }\end{array}$ & $\begin{array}{c}-0.011369 \\
(0.00907) \\
{[-1.25318]}\end{array}$ & $\begin{array}{c}0.066738 \\
(0.06066) \\
{[1.10029]}\end{array}$ & $\begin{array}{c}0.002702 \\
(0.00655) \\
{[0.41273]}\end{array}$ & $\begin{array}{l}0.692347 \\
(1.63715) \\
{[0.42290]}\end{array}$ & $\begin{array}{r}-0.000277 \\
(0.00321) \\
{[-0.08624]}\end{array}$ & $\begin{array}{c}0.003048 \\
(0.00182) \\
{[1.67334]}\end{array}$ & $\begin{array}{c}-0.004202 \\
(0.00814) \\
{[-0.51606]}\end{array}$ \\
\hline & $\begin{array}{c}\text { Permintaan } \\
\text { Komoditas Ekspor } \\
\text { non Pertanian } \\
(\text { E_C_N(-1)) }\end{array}$ & $\begin{array}{r}0.005909 \\
(0.00908) \\
{[0.65068]}\end{array}$ & $\begin{array}{r}-0.032930 \\
(0.06072) \\
{[-0.54232]}\end{array}$ & $\begin{array}{r}-0.002492 \\
(0.00655) \\
{[-0.38017]}\end{array}$ & $\begin{array}{r}-1.094761 \\
(1.63894) \\
{[-0.66797]}\end{array}$ & $\begin{array}{c}-0.001147 \\
(0.00321) \\
{[-0.35724]}\end{array}$ & $\begin{array}{r}-0.002365 \\
(0.00182) \\
{[-1.29667]}\end{array}$ & $\begin{array}{l}0.007635 \\
(0.00815) \\
{[0.93662]}\end{array}$ \\
\hline \multirow{3}{*}{$\begin{array}{l}\text { BLOK } \\
\text { PERMINTA- } \\
\text { AN ASET } \\
\text { FINANSIAL }\end{array}$} & $\begin{array}{c}\text { Permintaan M2 } \\
(\text { E_M2(-1)) }\end{array}$ & $\begin{array}{c}-0.031168 \\
(0.09271) \\
{[-0.33618]}\end{array}$ & $\begin{array}{r}-0.286998 \\
(0.61987) \\
{[-0.46300]}\end{array}$ & $\begin{array}{c}0.007963 \\
(0.06691) \\
{[0.11901]}\end{array}$ & $\begin{array}{r}-63.75010 \\
(16.7311) \\
{[-3.81028]}\end{array}$ & $\begin{array}{l}0.057631 \\
(0.03278) \\
{[1.75812]}\end{array}$ & $\begin{array}{c}-0.011827 \\
(0.01862) \\
{[-0.63528]}\end{array}$ & $\begin{array}{r}-0.179446 \\
(0.08321) \\
{[-2.15653]}\end{array}$ \\
\hline & $\begin{array}{l}\text { Permintaan Bond } \\
\text { Domestik } \\
(\text { E_B }(-1))\end{array}$ & $\begin{array}{l}0.003184 \\
(0.00766) \\
{[0.41587]}\end{array}$ & $\begin{array}{c}0.023019 \\
(0.05119) \\
{[0.44966]}\end{array}$ & $\begin{array}{r}-0.003855 \\
(0.00553) \\
{[-0.69765]}\end{array}$ & $\begin{array}{l}0.491963 \\
(1.38172) \\
{[0.35605]}\end{array}$ & $\begin{array}{c}-0.002533 \\
(0.00271) \\
{[-0.93567]}\end{array}$ & $\begin{array}{l}0.000672 \\
(0.00154) \\
{[0.43686]}\end{array}$ & $\begin{array}{c}0.004433 \\
(0.00687) \\
{[0.64512]}\end{array}$ \\
\hline & $\begin{array}{l}\text { Permintaan Bond } \\
\text { Luar Negeri } \\
\text { (E_BBIN }(-1))\end{array}$ & $\begin{array}{c}-0.009414 \\
(0.00709) \\
{[-1.32869]}\end{array}$ & $\begin{array}{c}0.089028 \\
(0.04737) \\
{[1.87936]}\end{array}$ & $\begin{array}{c}-0.006827 \\
(0.00511) \\
{[-1.33499]}\end{array}$ & $\begin{array}{c}-3.474708 \\
(1.27861) \\
{[-2.71758]}\end{array}$ & $\begin{array}{c}0.000475 \\
(0.00251) \\
{[0.18956]}\end{array}$ & $\begin{array}{c}0.001225 \\
(0.00142) \\
{[0.86068]}\end{array}$ & $\begin{array}{c}-0.004863 \\
(0.00636) \\
{[-0.76474]}\end{array}$ \\
\hline
\end{tabular}

Keterangan:

Angka di dalam ( ) adalah standard error

Angka di dalam [ ] adalah $t$-statistics

Sel yang diarsir menunjukkan siknifikan secara statitistik $($-statistics $>2)$ 
Tabel 7. Lanjutan

\begin{tabular}{|c|c|c|c|c|c|c|c|c|}
\hline BLOK & $\begin{array}{c}\text { Sumber } \\
\text { Disequilibrium } \\
\text { Error (Error } \\
\text { Coorection) } \\
\end{array}$ & $\begin{array}{l}\text { Produksi non } \\
\text { Pertanian } \\
\text { (D(LYN)) }\end{array}$ & $\begin{array}{l}\text { Permintaan } \\
\text { Modal non } \\
\text { pertanian } \\
(\mathrm{D}(\mathrm{LKN})) \\
\end{array}$ & $\begin{array}{c}\text { Permintaan } \\
\text { Tenaga Kerja } \\
\text { non Pertanian } \\
\text { D(LLN) } \\
\end{array}$ & $\begin{array}{l}\text { Suku Bunga } \\
\text { (D(r)) }\end{array}$ & $\begin{array}{c}\text { Upah rill } \\
\text { Tenaga Kerja } \\
\text { non Pertanian } \\
(\mathrm{D}(\mathrm{LWNPN})) \\
\end{array}$ & \begin{tabular}{|c|} 
Harga Material \\
Riil non \\
Pertanian \\
D(LPMNPN) \\
\end{tabular} & $\begin{array}{c}\text { Harga } \\
\text { komoditas non } \\
\text { Pertanian } \\
(\mathrm{D}(\mathrm{LPN})) \\
\end{array}$ \\
\hline \multirow{4}{*}{$\begin{array}{c}\text { BLOK } \\
\text { PERMINTA } \\
\text { AN KOMODI- } \\
\text { TAS }\end{array}$} & $\begin{array}{c}\text { Permintaan } \\
\text { komoditas pertanian } \\
\text { Impor } \\
(\text { E_C_BINA }(-1))\end{array}$ & $\begin{array}{c}0.004203 \\
(0.00883) \\
{[0.47604]}\end{array}$ & $\begin{array}{r}-0.128580 \\
(0.05903) \\
{[-2.17815]}\end{array}$ & $\begin{array}{r}-0.003328 \\
(0.00637) \\
{[-0.52233]}\end{array}$ & $\begin{array}{r}4.227669 \\
(1.59334) \\
{[2.65334]}\end{array}$ & $\begin{array}{r}-0.002185 \\
(0.00312) \\
{[-0.69983]}\end{array}$ & $\begin{array}{r}-0.000237 \\
(0.00177) \\
{[-0.13372]}\end{array}$ & $\begin{array}{r}0.004874 \\
(0.00792) \\
{[0.61512]}\end{array}$ \\
\hline & $\begin{array}{c}\text { Permintaan } \\
\text { Komoditas Pertanian } \\
\text { Domestik } \\
\text { (E_CA }(-1)\end{array}$ & $\begin{array}{r}-0.149810 \\
(0.09186) \\
{[-1.63083]}\end{array}$ & $\begin{array}{r}1.569147 \\
(0.61418) \\
{[2.55487]}\end{array}$ & $\begin{array}{r}-0.066268 \\
(0.06630) \\
{[-0.99952]}\end{array}$ & $\begin{array}{r}-35.65226 \\
(16.5774) \\
{[-2.15065]}\end{array}$ & $\begin{array}{r}-0.024214 \\
(0.03248) \\
{[-0.74553]}\end{array}$ & $\begin{array}{r}0.054326 \\
(0.01845) \\
{[2.94512]}\end{array}$ & $\begin{array}{r}0.073853 \\
(0.08245) \\
{[0.89577]}\end{array}$ \\
\hline & $\begin{array}{c}\text { Permintaan } \\
\text { Komoditas non } \\
\text { Pertanian } \\
\text { Domestik (E_CN(-1)) }\end{array}$ & $\begin{array}{l}-0.012066 \\
(0.06684) \\
{[-0.18053]}\end{array}$ & $\begin{array}{l}-0.724504 \\
(0.44688) \\
{[-1.62126]}\end{array}$ & $\begin{array}{r}-0.004693 \\
(0.04824) \\
{[-0.09729]}\end{array}$ & $\begin{array}{r}0.240264 \\
(12.0617) \\
{[0.01992]}\end{array}$ & $\begin{array}{r}-0.012657 \\
(0.02363) \\
{[-0.53558]}\end{array}$ & $\begin{array}{l}-0.016651 \\
(0.01342) \\
{[-1.24060]}\end{array}$ & $\begin{array}{l}-0.003783 \\
(0.05999) \\
{[-0.06306]}\end{array}$ \\
\hline & $\begin{array}{c}\text { Permintaan } \\
\text { Komoditas non } \\
\text { Pertanian Impor } \\
(\text { E_CBIN_N1(-1)) }\end{array}$ & $\begin{array}{c}0.002821 \\
(0.01704) \\
{[0.16553]}\end{array}$ & $\begin{array}{l}0.100464 \\
(0.11393) \\
{[0.88177]}\end{array}$ & $\begin{array}{r}0.001322 \\
(0.01230) \\
{[0.10745]}\end{array}$ & $\begin{array}{l}-4.728091 \\
(3.07522) \\
{[-1.53748]}\end{array}$ & $\begin{array}{c}-0.004865 \\
(0.00603) \\
{[-0.80742]}\end{array}$ & $\begin{array}{r}-0.002454 \\
(0.00342) \\
{[-0.71713]}\end{array}$ & $\begin{array}{l}0.007128 \\
(0.01529) \\
{[0.46604]}\end{array}$ \\
\hline & $\begin{array}{l}\text { Angka di dalam ( ) } \\
\text { Angka di dalam [ ] } \\
\text { Sel yang diarsir mer }\end{array}$ & an $t$-statsist & 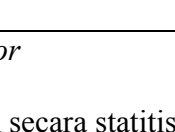 & 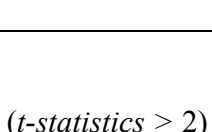 & & & & \\
\hline
\end{tabular}


Tabel 8. Koefisien Estimasi dari masing-masing Disequilibrium Error masing-masing Persamaan pada Setiap Blok terhadap Blok Permintaan Ekspor

\begin{tabular}{|c|c|c|c|c|c|c|c|}
\hline BLOK & Error Correction: & $\begin{array}{c}\text { Ekpor } \\
\text { Pertanian } \\
\text { (D(LC_A)) }\end{array}$ & $\begin{array}{l}\text { Ekspor non } \\
\text { Pertanian } \\
\text { (D(LC_N)) }\end{array}$ & $\begin{array}{c}\text { Real Ef. } \\
\text { Exchange Rate } \\
\text { (D(LREER)) }\end{array}$ & $\begin{array}{l}\text { Harga Ekspor } \\
\text { Pertanian } \\
\text { (D(LP_A)) }\end{array}$ & $\begin{array}{c}\text { Harga } \\
\text { Ekspor non } \\
\text { Pertanian } \\
\left(\mathrm{D}\left(\mathrm{LP} \_\mathrm{N}\right)\right) \\
\end{array}$ & $\begin{array}{c}\text { Belanja } \\
\text { Konsumsi } \\
\text { Dunia } \\
\text { (D(LX_BIN)) } \\
\end{array}$ \\
\hline \multirow{2}{*}{$\begin{array}{c}\text { BLOK } \\
\text { PERMINTAAN } \\
\text { EKSPOR }\end{array}$} & $\begin{array}{l}\text { Komoditas Pertanian } \\
(\text { E_C_A(-1)) }\end{array}$ & $\begin{array}{r}-1.129674 \\
(0.54985) \\
{[-2.05450]}\end{array}$ & $\begin{array}{r}-1.183502 \\
(0.52020) \\
{[-2.27511]}\end{array}$ & $\begin{array}{r}-0.183647 \\
(0.04384) \\
{[-4.18870]}\end{array}$ & $\begin{array}{r}-0.080539 \\
(0.05278) \\
{[-1.52584]}\end{array}$ & $\begin{array}{c}0.047964 \\
(0.06418) \\
{[0.74734]}\end{array}$ & $\begin{array}{c}0.000767 \\
(0.00467) \\
{[0.16420]}\end{array}$ \\
\hline & Komoditas non Pertanian & $\begin{array}{r}0.854436 \\
(0.48056) \\
{[1.77799]}\end{array}$ & $\begin{array}{l}0.907227 \\
(0.45464) \\
{[1.99548]}\end{array}$ & $\begin{array}{r}0.198792 \\
(0.03832) \\
{[5.18790]}\end{array}$ & $\begin{array}{l}0.047858 \\
(0.04613) \\
{[1.03742]}\end{array}$ & $\begin{array}{r}-0.057916 \\
(0.05609) \\
{[-1.03251]}\end{array}$ & $\begin{array}{r}-0.000529 \\
(0.00408) \\
{[-0.12970]}\end{array}$ \\
\hline \multirow{3}{*}{$\begin{array}{c}\text { BLOK } \\
\text { PRODUKSI } \\
\text { PERTANIAN }\end{array}$} & $\begin{array}{c}\text { Output } \\
(\text { E_YN(-1)) }\end{array}$ & $\begin{array}{r}0.857557 \\
(0.75177) \\
{[1.14071]}\end{array}$ & $\begin{array}{l}0.733488 \\
(0.71122) \\
{[1.03130]}\end{array}$ & $\begin{array}{r}-0.252704 \\
(0.05994) \\
{[-4.21568]}\end{array}$ & $\begin{array}{l}0.129634 \\
(0.07217) \\
{[1.79630]}\end{array}$ & $\begin{array}{l}0.055678 \\
(0.08775) \\
{[0.63452]}\end{array}$ & $\begin{array}{r}-0.003276 \\
(0.00638) \\
{[-0.51325]}\end{array}$ \\
\hline & $\begin{array}{l}\text { Permintaan Modal } \\
(\text { E_KN(-1)) }\end{array}$ & $\begin{array}{r}0.403438 \\
(0.44310) \\
{[0.91049]}\end{array}$ & $\begin{array}{r}0.415830 \\
(0.41920) \\
{[0.99196]}\end{array}$ & $\begin{array}{r}-0.046316 \\
(0.03533) \\
{[-1.31091]}\end{array}$ & $\begin{array}{r}0.063662 \\
(0.04254) \\
{[1.49666]}\end{array}$ & $\begin{array}{r}0.028035 \\
(0.05172) \\
{[0.54206]}\end{array}$ & $\begin{array}{r}-0.001017 \\
(0.00376) \\
{[-0.27025]}\end{array}$ \\
\hline & $\begin{array}{c}\text { Permintaan Tenaga Kerja } \\
(\text { E_LN }(-1))\end{array}$ & $\begin{array}{r}2.187485 \\
(4.60766) \\
{[0.47475]}\end{array}$ & $\begin{array}{r}1.988840 \\
(4.35913) \\
{[0.45625]}\end{array}$ & $\begin{array}{r}0.187025 \\
(0.36740) \\
{[0.50905]}\end{array}$ & $\begin{array}{r}-0.192748 \\
(0.44232) \\
{[-0.43577]}\end{array}$ & $\begin{array}{r}0.407256 \\
(0.53781) \\
{[0.75724]}\end{array}$ & $\begin{array}{r}0.021036 \\
(0.03912) \\
{[0.53767]}\end{array}$ \\
\hline terangan: & $\begin{array}{l}\text { Angka di dalam ( ) adalal } \\
\text { Angka di dalam [ ] adala } \\
\text { Sel yang diarsir menunjuk }\end{array}$ & $\begin{array}{l}\text { adard err } \\
\text { atistics }\end{array}$ & & $i c s>2$ ) & & & \\
\hline
\end{tabular}


Tabel 8. Lanjutan

\begin{tabular}{|c|c|c|c|c|c|c|c|}
\hline BLOK & Error Correction: & $\begin{array}{c}\text { Ekpor } \\
\text { Pertanian } \\
\text { (D(LC_A)) }\end{array}$ & $\begin{array}{l}\text { Ekspor non } \\
\text { Pertanian } \\
(\text { D(LC_N)) }\end{array}$ & $\begin{array}{c}\text { Real Ef. } \\
\text { Exchange Rate } \\
\text { (D(LREER)) }\end{array}$ & $\begin{array}{c}\text { Harga Ekspor } \\
\text { Pertanian } \\
\text { (D(LP_A)) }\end{array}$ & $\begin{array}{c}\text { Harga } \\
\text { Ekspor non } \\
\text { Pertanian } \\
\left(\mathrm{D}\left(\mathrm{LP} \_\mathrm{N}\right)\right) \\
\end{array}$ & $\begin{array}{c}\text { Belanja } \\
\text { Konsumsi } \\
\text { Dunia } \\
\text { (D(LX_BIN)) }\end{array}$ \\
\hline \multirow{6}{*}{$\begin{array}{c}\text { BLOK } \\
\text { PRODUKSI NON } \\
\text { PERTANIAN }\end{array}$} & $\begin{array}{l}\text { Permintaan Modal } \\
\text { (E_KA(-1)) }\end{array}$ & $\begin{array}{l}0.087616 \\
(0.69337) \\
{[0.12636]}\end{array}$ & $\begin{array}{r}0.090019 \\
(0.65597) \\
{[0.13723]}\end{array}$ & $\begin{array}{r}-0.033982 \\
(0.05529) \\
{[-0.61465]}\end{array}$ & $\begin{array}{r}-0.013640 \\
(0.06656) \\
{[-0.20493]}\end{array}$ & $\begin{array}{c}0.015340 \\
(0.08093) \\
{[0.18954]}\end{array}$ & $\begin{array}{c}0.000352 \\
(0.00589) \\
{[0.05984]}\end{array}$ \\
\hline & & & & & & & \\
\hline & \multirow{3}{*}{$\begin{array}{l}\text { Permintaan Tenaga Kerja } \\
\text { (E_LA }(-1))\end{array}$} & -1.687409 & -1.692436 & 0.202035 & -0.558929 & -0.124823 & 0.025318 \\
\hline & & $(2.88515)$ & $(2.72953)$ & $(0.23005)$ & $(0.27696)$ & $(0.33676)$ & $(0.02450)$ \\
\hline & & {$[-0.58486]$} & {$[-0.62005]$} & {$[0.87821]$} & {$[-2.01807]$} & {$[-0.37066]$} & {$[1.03344]$} \\
\hline & $\begin{array}{c}\text { Output } \\
(\text { E_YA(-1)) }\end{array}$ & $\begin{array}{r}3.399832 \\
(0.89771) \\
{[3.78722]}\end{array}$ & $\begin{array}{r}3.174682 \\
(0.84929) \\
{[3.73803]}\end{array}$ & $\begin{array}{r}0.137047 \\
(0.07158) \\
{[1.91458]}\end{array}$ & $\begin{array}{r}-0.068672 \\
(0.08618) \\
{[-0.79688]}\end{array}$ & $\begin{array}{r}-0.046477 \\
(0.10478) \\
{[-0.44356]}\end{array}$ & $\begin{array}{c}0.009513 \\
(0.00762) \\
{[1.24800]}\end{array}$ \\
\hline & & & & & & & \\
\hline & E_M2(-1) & $\begin{array}{r}1.876505 \\
(4.35488) \\
{[0.43090]}\end{array}$ & $\begin{array}{r}2.101073 \\
(4.11999) \\
{[0.50997]}\end{array}$ & $\begin{array}{r}1.156153 \\
(0.34724) \\
{[3.32953]}\end{array}$ & $\begin{array}{r}-1.375521 \\
(0.41805) \\
{[-3.29033]}\end{array}$ & $\begin{array}{r}-1.289074 \\
(0.50831) \\
{[-2.53601]}\end{array}$ & $\begin{array}{l}0.047243 \\
(0.03698) \\
{[1.27759]}\end{array}$ \\
\hline & E_B(-1) & $\begin{array}{r}0.788017 \\
(0.37129) \\
{[2.12236]}\end{array}$ & $\begin{array}{l}0.752586 \\
(0.35127) \\
{[2.14250]}\end{array}$ & $\begin{array}{r}-0.033023 \\
(0.02961) \\
{[-1.11542]}\end{array}$ & $\begin{array}{r}-0.031754 \\
(0.03564) \\
{[-0.89091]}\end{array}$ & $\begin{array}{r}-0.086731 \\
(0.04334) \\
{[-2.00127]}\end{array}$ & $\begin{array}{r}0.002444 \\
(0.00315) \\
{[0.77510]}\end{array}$ \\
\hline & E_BBIN(-1) & $\begin{array}{r}0.788265 \\
(0.30668) \\
{[2.57035]}\end{array}$ & $\begin{array}{c}0.802091 \\
(0.29013) \\
{[2.76455]}\end{array}$ & $\begin{array}{c}0.026590 \\
(0.02445) \\
{[1.08740]}\end{array}$ & $\begin{array}{r}0.077347 \\
(0.02944) \\
{[2.62731]}\end{array}$ & $\begin{array}{r}-0.002385 \\
(0.03580) \\
{[-0.06662]}\end{array}$ & $\begin{array}{c}-0.001055 \\
(0.00260) \\
{[-0.40512]}\end{array}$ \\
\hline
\end{tabular}

Angka di dalam ( ) adalah standard error

Angka di dalam [ ] adalah t-statistics

Sel yang diarsir menunjukkan siknifikan secara statitistik $(t$-statistics $>2)$ 
Tabel 8. Lanjutan

\begin{tabular}{|c|c|c|c|c|c|c|c|}
\hline BLOK & Error Correction: & $\begin{array}{c}\text { Ekpor } \\
\text { Pertanian } \\
\text { (D(LC_A)) }\end{array}$ & $\begin{array}{c}\text { Ekspor non } \\
\text { Pertanian } \\
\left(D\left(L C \_N\right)\right)\end{array}$ & $\begin{array}{c}\text { Real Ef. } \\
\text { Exchange Rate } \\
\text { (D(LREER)) }\end{array}$ & $\begin{array}{c}\text { Harga Ekspor } \\
\text { Pertanian } \\
\text { (D(LP_A)) }\end{array}$ & $\begin{array}{c}\text { Harga } \\
\text { Ekspor non } \\
\text { Pertanian } \\
(\text { D(LP_N }))\end{array}$ & $\begin{array}{c}\text { Belanja } \\
\text { Konsumsi } \\
\text { Dunia } \\
\text { (D(LX_BIN)) }\end{array}$ \\
\hline \multirow{4}{*}{$\begin{array}{c}\text { BLOK } \\
\text { PERMINTAAN } \\
\text { KOMODITAS }\end{array}$} & $\begin{array}{l}\text { Permintaan Komoditas } \\
\text { Pertanian Impor } \\
\text { (E_C_BINA(-1)) }\end{array}$ & $\begin{array}{r}0.304442 \\
(0.55441) \\
{[0.54913]}\end{array}$ & $\begin{array}{l}0.278817 \\
(0.52451) \\
{[0.53158]}\end{array}$ & $\begin{array}{r}0.016289 \\
(0.04421) \\
{[0.36848]}\end{array}$ & $\begin{array}{l}0.017421 \\
(0.05322) \\
{[0.32734]}\end{array}$ & $\begin{array}{c}0.058682 \\
(0.06471) \\
{[0.90682]}\end{array}$ & $\begin{array}{l}0.001389 \\
(0.00471) \\
{[0.29500]}\end{array}$ \\
\hline & $\begin{array}{c}\text { Permintaan Komoditas } \\
\text { Pertanian } \\
(\text { E_CA }(-1))\end{array}$ & $\begin{array}{r}6.179666 \\
(6.27061) \\
{[0.98550]}\end{array}$ & $\begin{array}{r}6.381458 \\
(5.93238) \\
{[1.07570]}\end{array}$ & $\begin{array}{r}-0.187925 \\
(0.50000) \\
{[-0.37585]}\end{array}$ & $\begin{array}{r}1.366378 \\
(0.60195) \\
{[2.26991]}\end{array}$ & $\begin{array}{l}1.186381 \\
(0.73192) \\
{[1.62093]}\end{array}$ & $\begin{array}{r}-0.031069 \\
(0.05325) \\
{[-0.58350]}\end{array}$ \\
\hline & $\begin{array}{c}\text { Permintaan Komoditas } \\
\text { non Pertanian } \\
\text { (E_CN(-1)) }\end{array}$ & $\begin{array}{r}-8.354533 \\
(4.32449) \\
{[-1.93191]}\end{array}$ & $\begin{array}{r}-8.304403 \\
(4.09124) \\
{[-2.02980]}\end{array}$ & $\begin{array}{r}0.249463 \\
(0.34482) \\
{[0.72346]}\end{array}$ & $\begin{array}{r}-0.203128 \\
(0.41513) \\
{[-0.48931]}\end{array}$ & $\begin{array}{r}0.084482 \\
(0.50476) \\
{[0.16737]}\end{array}$ & $\begin{array}{l}0.036179 \\
(0.03672) \\
{[0.98526]}\end{array}$ \\
\hline & $\begin{array}{c}\text { Permintaan Komoditas } \\
\text { non Pertanian Impor } \\
\text { (E_CBIN_N1(-1)) }\end{array}$ & $\begin{array}{r}-2.724061 \\
(1.14299) \\
{[-2.38328]}\end{array}$ & $\begin{array}{r}-2.580978 \\
(1.08134) \\
{[-2.38684]}\end{array}$ & $\begin{array}{r}-0.081502 \\
(0.09114) \\
{[-0.89427]}\end{array}$ & $\begin{array}{r}-0.072743 \\
(0.10972) \\
{[-0.66298]}\end{array}$ & $\begin{array}{r}-0.061322 \\
(0.13341) \\
{[-0.45964]}\end{array}$ & $\begin{array}{r}-0.002227 \\
(0.00971) \\
{[-0.22950]}\end{array}$ \\
\hline
\end{tabular}

Keterangan:

Angka di dalam ( ) adalah standard error

Angka di dalam [ ] adalah $t$-statistics

Sel yang diarsir menunjukkan siknifikan secara statitistik $(t$-statistics $>2)$ 